\title{
GEÇ TUNÇ ÇAĞI TROYA SAVUNMA HENDEĞİ ARAŞTIRMALARINA JEOARKEOLOJIK KATKILAR
}

\author{
[GEOARCHAEOLOGICAL CONTRIBUTION TO RESEARCH ON THE LATE BRONZE \\ AGE DEFENSIVE DITCH OF TROIA]
}

\author{
İlhan KAYAN- Mehmet DOĞAN - Rifat İLHAN - Aylin KARADAŞ - \\ Doğukan Doğu YAVAŞLI - Rüstem ASLAN
}

\begin{abstract}
Anahtar Kelimeler
Troya, Tunç Çă̆ı, Savunma hendeği, Jeoarkeoloji, Delgi sondaj.
\end{abstract}

Keywords

Troia, Bronze Age, Defensive ditch, Geoarchaeology, Core drilling.

\section{ÖZET}

Troya kazıları kapsamında, 2007-2011 yılları arasında, Tunç Çă̆l ve sonrasındaki antik çağlarda Troya Aşağı Kentini güneyden çevreleyen savunma hendeğinin doğudaki uzanışını belirlemek amacıyla, başta jeofizik olmak üzere çeşitli yöntemlerle yoğun araştırmalar yapılmıştır. Bu çalışmalara ekibimiz çok sayıda çakma-delgi sondaj yaparak katkıda bulunmuştur. Bu yazı, çalışmalarımızın jeoarkeoloji araştırma konu ve yöntemleri bakımından özgün bir örnek oluşturacağı düşünülerek hazırlanmıştır. Çalışmalar kapsamında, hendeğin doğuda kuzeydoğuya yönelen kesiminde, öngörülen uzanımına dik doğrultuda yapılan toplam 201 çakma-delgi sondajla 10 adet kesit oluşturulmuştur. Buna göre, burada bütünüyle Troya'nın yıkıntı enkazından oluşan, yapı taşları ile dolu, 2-3 m kalınlıkta bir yüzey örtüsü ile bunun altında kireçli, killi, kumlu, güneydoğuya çok az ĕgimli anakaya tabakaları (Üst Miosen) bulunmaktadır. Örtü altında anakaya yüzeyindeki küçük çukurlukların hendek uzantısına ait olduğunu belirlemek zor olmakla birlikte, anakaya ile örtüdeki blok taşların litolojik farklılıklarının ve özellikle bulunan çanak çömlek klrıkları gibi arkeolojik materyalin değerlendirilmesi ile hendek uzanımı bir yere (I-K/24-25:2009-1) kadar izlenebilmiş, fakat buradan kuzeydoğuya doğru hendekle ilgili somut veri sağlanamamıştır. Sonuç olarak, sondaj çalışmalarının jeofizik yöntemlerle belirlenen anomali çizgilerinin test edilmesinde ve arkeologların farklı dönemleri temsil eden yüzey örtüsü katmanlarını değerlendirmeleri için örnek sağlanmasında önemli katkısı olmuştur. Böylece kazı yapılamayan yerlerde hendek uzanımı ile ilgili bilgi edinilmiş ve gereksiz kazı yapılması önlenmiştir.

\begin{abstract}
Within the scope of Troy excavations, in 2007-2011, intensive researches were carried out with various methods, especially geophysics, in order to determine the eastern extension of the defense ditch (moat) along the southern surrounding of the Lower City of Troy during the Bronze Age and later antiquity. Our team contributed to these studies by making numerous percussion borehole-drillings. This paper has been prepared with the aim of creating a unique example in terms of geoarchaeological research subjects and methods. Within the scope of the studies, a total of 201 borehole-drillings made perpendicular to the projected extension of the trench in the northeastern part of the ditch and formed 10 sections. Accordingly, there is a 2-3 m thick surface deposit-cover consisting of building debris of Troy, and underneath it is limy, clayey, sandy bedrock layers (Upper Miocene), slightly dipping southeast. Although it is difficult to recognize that the small pits on the bedrock surface under the cover belong to the trench extension, it could be traced to a location (I-K/24-25: 2009-1) by determining the lithological differences between the bedrock and the large stones and especially the archaeological material such as potsherds found; but there is no concrete data on the ditch from the northeast. As a result, it has made a significant contribution to the testing of anomaly lines determined by geophysical methods and to provide samples for archaeologists to evaluate the surface cover layers representing different periods. Thus, information was obtained about
\end{abstract}


been prepared with the aim of creating a unique example in terms of geoarchaeological research subjects and methods. Within the scope of the studies, a total of 201 borehole-drillings made perpendicular to the projected extension of the trench in the northeastern part of the ditch and formed 10 sections. Accordingly, there is a 2-3 m thick surface deposit-cover consisting of building debris of Troy, and underneath it is limy, clayey, sandy bedrock layers (Upper Miocene), slightly dipping southeast. Although it is difficult to recognize that the small pits on the bedrock surface under the cover belong to the trench extension, it could be traced to a location (I-K/24-25: 2009-1) by determining the lithological differences between the bedrock and the large stones and especially the archaeological material such as potsherds found; but there is no concrete data on the ditch from the northeast. As a result, it has made a significant contribution to the testing of anomaly lines determined by geophysical methods and to provide samples for archaeologists to evaluate the surface cover layers representing different periods. Thus, information was obtained about extension of the trench in places where excavation could not be done, and unnecessary excavation was prevented.

\section{Giriş}

1988 y1lında Tübingen Üniversitesi (Almanya) Prehistorya Enstitüsü'nün (Institüt für Ur- und Frühgeschihte Und Archäologie des Mittelalters) Troya Projesi kapsamında, T.C. Kültür Bakanlığ1 izniyle başlayan Troya araştırma, kazı ve restorasyon çalışmaları 2005 yılına kadar Prof. Dr. Manfred Osman Korfmann başkanlığında sürmüş, O’nun çok disiplinli (multidisciplinary) çalışmaları destekleyen, heyecanlı ve çok başarılı yönetimi, Troya'yı yurt içinde ve yurt dışında hep gündemde tutmuş, projenin güçlü kurumlarca desteklenmesini sağlamıştır. Prof. Korfmann'ın vefatından sonra, 2013 yılına kadar Prof. Dr. Ernst Pernicka tarafından yayın ağırlıklı yönetilen çalışmalar, o tarihten beri Prof. Dr. Rüstem Aslan başkanlığında sürmektedir.

Troya, kuzeybatı Anadolu'da en iyi araştırılmış Tunç Çağı yerleşmelerinden biri olmasinın yanında, Homeros'un İliada destanı ile Batı kültüründe çok iyi tanınan, ilgi duyulan önemli bir antik yerleşme yeridir (Fig. 1). Bu nedenle, özellikle 19. yüzyıldan beri pek çok gezgin ve araştırmacının uğrak yeri olmuştur. Schliemann'1n 1870-1890 kazılar1 ve bulunan hazinelerin yurt dışına kaçırılması Troya'ya duyulan ilgi ve merakı artırmıştır. Schliemann sonrasında, özellikle W. Dörpfeld ve C.W. Blegen tarafından yapılan arkeolojik kazı ve araştırmalarla Troya'nın en az 5000 yıllık geçmişinde, Roma Çağı sonuna kadar dokuz yapılaşma evresi ayrılmıştır (Fig. 2). Bu süreçte doğal çevrede meydana gelen değişmeler arkeologlarca hep dikkate alınmaya çalışılmış, ancak önceki aşamalarda bunun için özgün bir araştırma yapılmamıştır. Bu nedenle, 1982 de Beşige'de başlayan ve 1988 de Troya'da devam eden yeni proje döneminde Prof. Korfmann çevresel özelliklerin incelenmesine, çevresel değişmelerin arkeolojik dönemlerle ilişkilendirilmesine özel bir önem vermiştir. Prof. Kayan'ın 1983 de projeye katılımı, Prof. Korfmann'ın bu amaçla yaptığı davet üzerine olmuştur. Troya geniş çevresindeki (Troas) jeolojik-jeomorfolojik araştırmalar ve haritalama çalışmaları sonrasında, ağırlıklı olarak yakın çevredeki alüvyal düzlüklerde sığ (çoğunlukla $20 \mathrm{~m}$ ye kadar derinlikte) delgi sondajlar yapılmış, sedimantolojik birimler tanımlanmış, bunların yüzey altındaki dağılımı ve C14 yöntemi ile tarihlendirilmesi sağlanmıştır. $\mathrm{Bu}$ bilgiler, zaman içinde çevrede meydana gelen coğrafi değişmelerin belirlenmesinde ve gerekli görülen zamanlar için paleocoğrafya haritalarının çizilmesinde ana veri kaynağını oluşturmuştur. Örneğin kıyı çizgisi değişmeleri, buna göre eski liman yerleri, savaş alanları, kentin denizden yararlanma olanakları, tarım, erozyon gibi konularda arkeologlarca çok sorulan soruların cevaplanmasına çalışılmıştır. Zaman içinde gelişmelere ve farklı amaçlara göre değişik yöntem ve araçlarla yapılan delgi sondajların sayısı, kazı alanı içindeki test sondajları dışında, 2011 yılında 327 ye ulaşmıştır. $\mathrm{Bu}$ çalışmaların sonuçları çoğunlukla Troya Projesinin yıllık yayını olan Studia Troica'da yayımlanmıştır. ${ }^{1}$

Troya kazı alanında yapılan arkeolojiye yardımcı araştırmalardan bir bölümünü de jeofizik prospeksiyonlar oluşturmuştur. İlk yillarda Dr. Jansen tarafından yapılan bu çalışmalar,

1 Kayan 1995: 211-235; Kayan 1996: 239-249; Kayan 1997: 489-507; Kayan 2014: 694-727; Kayan: 2019: 277-291. 
zaman zaman projeye katılan başka jeofizik uzmanlarının da katkılarıyla genişletilmiş, Troya Așağ 1 Kent alanı magnetometrik olarak taranmıştır. Bu ölçümlerin sonucunda özellikle Helenistik ve Roma çağlarına ait Aşağı Kent alanının yüzey altındaki planı çıkarılmış, bunun kazı çalışmalarının yönlendirilmesine büyük katkıları olmuştur. ${ }^{2}$

Jeofizik prospeksiyonlarda belirlenmesine çalişılan yapılardan biri de Aşağ 1 Kenti güneyden çevreleyen savunma sistemi olmuştur. Bunun öncelikle bir sur duvarı olması beklenmekle birlikte, özellikle Geç Tunç Çağ 1 (Troya VI) için, o zamanlarda Anadolu-Hitit kentlerinde yaygın olarak kullanıldığ 1 bilinen bir savunma hendeğinin de bu sistemin bir parçası olabileceği öngörülmüştür. ${ }^{3}$ Sur ve bunun dișındaki hendekten oluşan savunma sisteminin bir önemi de kentin büyüklüğünün ve nüfusunun belirlenmesindeki anlamından gelmektedir. $\mathrm{Bu}$ nedenle arkeologlar bu konu üzerinde önemle durmuş, savunma sisteminin uzanışının belirlenmesine çalışmışlardır. Manyetometrik taramalarda belirlenen çizgisel anomaliler Aşağ Kent güneyinde savunma hendeğinin yerini göstermiş, buralarda yapılan kazılar hendeğin varlığını doğrulamıştır (Fig. 3). Aşağı Kentin güney ve batı kesimlerinde yıllarca süren çalıșmalarla savunma sistemi belirlendikten sonra 2007 y1lında gözler doğuya çevrilmiş, hendeğin burada kuzeye mi, yoksa kuzeydoğuya mı uzandiğ1 ilgi konusu olmuştur. Kuşkusuz, hendeğin kuzey yerine kuzeydoğu veya doğuya yönelmesi kent alanının daha geniş olduğu anlamına gelmektedir. Bu konudaki araștırmalarda, bu kesimdeki yüzey örtüsü kalınl1ğının ve alttaki anakaya yüzey morfolojisinin bilinmesi de önemli bir gereksinim olarak değerlendirilmiştir.

Jeofizik araştırmalar Aşağı Kent alanının doğu kesiminde de sokak ve binalarıyla HelenistikRoma dönemlerinin kent dokusunu ortaya koymuş olmakla birlikte, hendek uzantısının belirlenmesinde yeterli olamamıştır. Bunun en önemli nedeni, bu alanın çok kullanılması, her

2 Jansen vd.1998: 275-284; Jansen vd. 2003: 325-340; Jansen 2006: 309-316; Becker vd. 1993: 117-134; Becker vd. 1994: 105-115; Blindow vd. 2000: 123-133; Hübner ve Giese 2006: 125-129.

3 Jablonka vd. 1994: 51-73. yeni evrede önceki yüzeyin fazla tahrip edilmesidir. Bunun yanısıra, eğer burada hendek devam ediyorsa, bunun üst yapı katmanlarının taşları ile dolduğu, bu nedenle manyetik ölçümlerde tanınamaz duruma gelmiş olabileceği de varsayımlar arasında değerlendirilmiştir. Mümkün olan yöntemlerin denenmesi amacryla, muhtemel uzantı üzerinde 2007 yılında ayrıca 11 elektrik rezistivite profili çıkarılmış, ancak bunlarda da hendek uzanımını yansitan kesin bulgular sağlanamamıştır. ${ }^{4}$ Kuşkusuz, bu konuda en güvenilir yol, alanın bütünüyle kazılmasıdır. Ancak bu, Geç Tunç Çağı hendeğine ulaşabilmek için üstteki Roma ve Helenistik katmanların kaldırılması gerektiği için hem arkeolojik bakımdan hem de zaman ve ekonomik bakımdan uygulanması zor bir seçenek olarak değerlendirilmiş, hendek uzanımının olabildiğince pratik bir yoldan belirlenmesi istenmiştir.

$\mathrm{Bu}$ aşamada hendeğin muhtemel uzantı alanında çakma-delgi sondajlarla profiller çıkarılarak uzanışının belirlenebileceği düşünülmüştür. Ancak, jeofizik ölçümlerde olduğu gibi, taşlı dolguların hendek içinde bulunan daha sonraki yapı evrelerinin duvarlarına $\mathrm{m} 1$ ait olduğunun, yoksa anakayaya mı ulaşıldığının anlaşılması her zaman mümkün olamayacağı için bu yöntemin de hendeğin izlenmesinde tam sonuç veremeyeceği değerlendirmesi yapılmıştır. Bununla birlikte, böyle bir çalışmanın denenmesine karar verilmiş ve 2008, 2009, 2010, 2011 yıllarında toplam 10 profil çizgisi üzerinde 201 i çakma olmak üzere yüzlerce delgi sondaj yapılmıştır. Bu sondajlar için iki araç seti kullanılmıştır.

\section{Hidrolik donanımlı Unimog iş makinesi ile burgu-delgiler (auger drilling).}

Prof. Korfmann'ın Troya projesine başladığ 1 1988 yılında Mercedes (Daimler-Benz), projenin ana sponsoru olmuş ve kazı çalışmalarına çok amaçlı bir Unimog iş makinesi vermiştir. Önündeki büyük kepçeden ayrı olarak arkasına bir küçük kepçe takılabilen bu aracın, gerektiğinde küçük kepçesi çıkarılarak yerine bizim delgi sondajlarımızda kullanılmak üzere bir burgu-delici (auger driller) takılabilmektedir. Hidrolik güçle döndürülerek yere girilen $6 \mathrm{~cm}$ çapında ve $1,5 \mathrm{~m}$ uzunluğundaki spiral

4 Jablonka vd. 2009: 3-32. 
burgular, dikey olarak yine hidrolik güçle çekilmekte ve spiral boşluğu dolduran materyal yüzey altına ait değerlendirmeler için örnek olarak kullanılmaktadır (Fig. 4). Aracın güçlü ve hızlı olması, bu yolla yapılan çalışmaların olumlu tarafidır. Ancak, demir burgu dönerek yere girdiğinden, az olmayan hacmi kadar materyal spiral boşlukta yukariya itilmekte ve alınan örneklerin gerçek dikey konumlarını belirlemek mümkün olmamaktadır. Ayrıca, kuru yüzey örtüsü veya dolgu katmanı burgu ile ufalanarak karışmakta, niteliği bozulmakta, daha burgu yere girerken delikten ögütülerek toz haline gelmiş kuru bir karışım çıkmaktadır. Konu ile ilgili olarak daha önemli bir olumsuzluk ise güçlü giriş sırasında yüzey altındaki fazla pekişmemiş anakaya veya yapı yıkıntısı taşların da delinip geçilebilmesi, bu nedenle yüzey dolgusundaki blok yapı taşları ile anakayanın ayırt edilmesindeki zorluktur. $\mathrm{Bu}$ olumsuzluğu, bu alanda anakayanın nispeten az pekişmiş, kireçli-killi-kumlu Neojen (Üst Miosen) sı̆̆ deniz sedimanlarından oluşmas1 da artırmakta, burgu demirler Unimog'un gücüyle anakaya içine dahi girebilmektedir. $\mathrm{Bu}$ nedenlerle Unimog, anakaya üzerindeki bir hendek oyuntusunun belirlenmesinde her yerde yararlı olamamıştır.

\section{Cobra delici ile çakmalı delgiler (percussion drilling).}

Cobra delici, taşınabilir bir kompresör motorudur (Fig. 5). Bunun ucuna $1 \mathrm{~m}$ uzunlukta, değişik çaplarda $(3,5 \mathrm{~cm}, 5 \mathrm{~cm}, 6 \mathrm{~cm})$ oluk şeklinde delici çelik uçlardan biri takılarak yere çakılmakta, daha derinlere inmesi için de 1 m'lik uzatma boruları eklenmektedir. Yere çakılan oluk uç ve borular ayrı bir hidrolik motorla çekilmekte ve oluk içindeki materyal, inilen derinliğe ait sediman örneği olarak değerlendirilmektedir. Oluk içinde bir miktar sıkıșma ve pekişme olsa bile, materyalin gerçek düşey konumu tam olarak belirlenebilmekte, küçük nesneler (çanak-çömlek kırıkları, kavkı, kemik parçaları gibi) niteliği bozulmadan alınabilmektedir. Ancak, pekişmemiş alüvyal sediman alanları için tasarlanmış olan Cobra delici Unimog kadar güçlü olmadığından, yüzey altındaki taşlar delginin ilerlemesini engellemekte, bu nedenle taşlı ortamlarda çalışıldığında güçlüklerle karşılaşılmaktadır. Buna rağmen, Troya Aşağı Kent savunma hendeğinin kuzey veya kuzeydoğuya uzanımını araștırırken Cobra delgi sondajlar bugünkü yüzey altında anakaya yüzeyindeki çukurlukların belirlenmesinde beklenenden daha güvenilir sonuçlar vermiştir. $\mathrm{Bu}$ çalışmada en büyük olumsuzluk, delici uç bir taşa dayandığında bunun anakaya mı, yoksa yüzey örtüsündeki iri bir yıkıntı taşına $\mathrm{m} 1$ ait olduğunun kolay anlaşılamamasıdır. Bunu aşmak için yüzeye yakın derinlikte taşla karşılaşıldığında delgi noktası küçük mesafelerle değiştirilmiş̧, taşlar arasından Cobra delicinin geçebileceği bir boşluk bulunmaya çalışılmıştır. Ayrıca deneyim ve jeolojik yap1 ile ilgili bilgiler de delgiyi durduran taşın yüzey örtüsü içinde bir blok mu, yoksa anakaya mı olduğu konusunda karar vermeyi kolaylaştırmıștır.

\section{Troya Savunma Hendeği üzerinde yapılan önceki çalışmalar ve sağlanan bilgiler}

1988 yılında başlayan yeni dönem Troya kazıları kapsamında ilk yıllardan itibaren yapılan jeofizik prospeksiyonlarda (fluxgate-gradiometer ve caesium-magnetometer), Troya İç Kalesinin 400 m kadar güneyinde bir anomali çizgisi belirlenmiştir. İlk aşamada anomalinin bir savunma duvarına ait olduğu düşünülmüş, ancak yapılan kazılarda bunun Troya VI döneminde Troya Aşağı Kentini güneyden çevreleyen bir savunma hendeğine ait olduğu anlaşılmıștır. ${ }^{5}$ Kenti savunmak, kente saldıran savaș arabalarını kent dıșında durdurmak amacyyla oluşturulduğu kabul edilen hendeğin, z 29-A 29 grid karelerindeki (Fig. 3) kazilarda, birkaç metre kalınlıktaki yüzey örtüsü altında bulunan Neojen kireçtaşı, kiltaşı, kumtaş1 tabakalarına $1 \mathrm{~m}$ kadar derinlikte, $3 \mathrm{~m}$ kadar genişlikte kazılarak yapıldığı belirlenmiştir. ${ }^{6}$ Savunma sisteminin diğer bir unsuru olarak bulunması gereken duvarın (sur) ise Roma döneminde, İlion kentinin inșası sırasında bütünüyle yok edildiği anlaşılmıștır. Bununla birlikte, 1995 y1lında y 28/29 karelerindeki (Fig. 3) kazılarda hendek üzerinde geçit amaçlı bir bölümün bırakıldığ 1 , bunun gerisinde (iç kesiminde) bir çitin ve bunun üzerinde de hendekteki geçide uygun, 5,2 m genişlikte bir açıklığı bulunduğu belirlenmiştir. Öte yandan, hendek dolgusunun yüzey örtüsünden farklı olduğu dikkati çekmiş, hendek dibinde MÖ 15.

\footnotetext{
5 Korfmann 1993: 117-134.
}

6 Jablonka vd. 1994: 51-73. 
yüzyıla ait çanak çömlek parçalarının bulunması, hendeğin açılış ve dolma aşamalarının zamanlarıyla (Geç Tunç Çağı - Troya VI) ilgili bilgi vermiştir.?

Daha sonra, batıda, ana hendeğin 80-100 m kadar güneyinde (dışında), g 28 karesinde yap1lan kazıda, benzer şekilde ikinci bir hendeğin varlığı ortaya çıkarılmıştır (Fig. 3). İlki gibi anakayaya kazılmış, tabanı düz bu hendekte yapılan incelemeler bunun Troya VI veya Troya VIIa dönemlerine ait olduğunu göstermiştir. Aynı dönemlerde dolmaya başlayan hendek üzerinde Roma Çağında (Troya IX) V profilli yeni bir hendeğin kazıldığı anlaşılmıştır. Bunun doğusundaki s 34 açmasında ise dıș kanalın $9 \mathrm{~m}$ kadar genişlikte olduğu görülmüş, bunun Hellenistik Çağ sonlarına doğru (Troya VIII) dolduğu anlaşılmıştır. Burada da Troya VI buluntularına rastlanması, bunun da Troya VI hendek sisteminin bir parçası olduğunu göstermiştir. Sonuç olarak, doğuda aynı doğrultudaki kazı buluntularıyla birlikte gözönüne alındığında Troya VIa hendeğinin dışında, ona paralel ikinci bir hendeğin varlığ 1 , Helenistik çağda dış hendeğin genişletilmiş bölümü içinde su bulunduğu, Roma atıksu sisteminin bu hendeğe bağlandığ değerlendirmeleri yapılmıştır. ${ }^{8}$

Tunç Çağında Troya Aşağı Kentini güneyden çevreleyen savunma hendeğinin batıya ve doğuya uzanımlarını, hendeğin İç Kale ile olan bağlantılarını belirlemek için 19961997 yıllarında yeni jeofizik araștırmalar yapılmıştır.9

$\mathrm{Bu}$ aşamada, batıdaki yapay mağara önünde yapılan elektromanyetik çalışmalarda, çizgisel bir anomali belirlenmiştir ${ }^{10}$ (Fig. 3). Buradaki p 12 kazısında anakayaya oyulmuş, $1 \mathrm{~m}$ kadar derinlikte, $4 \mathrm{~m}$ genişlikte düz bir tabanı olan, dik kenarlı bir hendek bölümü açığa çıkarılmıştır. Hendeğin ince taneli, kumlu dolgusu içinde sadece Tunç Çağı (Troya VI ve muhtemelen Troya VIIa) çanak çömlek kırıkları, hayvan kemikleri ve yanık artıkları (odun kömürü kırıntıları) bulunmuștur. Buna karşılık f

\footnotetext{
7 Korfmann 1996: 1-64; Jablonka 1996: 65-96.

8 Korfmann 1993: 1-39; Jablonka 1996: 65-96.

9 Jansen vd. 1998: 275.

10 Blindow vd. 2000: 123.
}

26 ve g 28 açmalarında Tunç Çă̆ına ait hiçbir kalıntı bulunmamıştır. Bunun nedeni, daha geniş ve derin olan Helenistik-Roma çağlarındaki hendeğin açılması sırasında meydana gelen tahribat olarak yorumlanmıştır. ${ }^{11} \mathrm{Bu}$ bilgiler Geç Troya VI/VIIa Aşağı Kentinin batıdaki sınırının belirlenmesini de sağlamıștır. Buna göre Aşağı Kent, İç Kale dışında oldukça geniş bir alan kaplamakta, güneybatı sınırı plato sırtının eteğinden ovaya doğru $120 \mathrm{~m}$ kadar daha batıda bulunmaktadır. Diğer bir önemli husus da su temini için kullanılan yapay mağaranın Tunç Çağı kent alanı içinde bulunmasidır (Fig. 3). ${ }^{12}$

Troya Tunç Çă̆ı savunma hendeğinin batı uzantısının belirlenmesi için yapılan manyetik jeofizik prospeksiyonlar ve buna dayanan kazilardan sonra, 2002-2005 y1llar1 arasinda Aşağ1 Kentin doğu kesiminde yeni jeofizik prospeksiyon (caesium magnetometer) çalıșmaları yapılmış ve sonuçları önceki bulgularla birleştirilmiştir. Sağlanan magnetogram'ların değerlendirilmesiyle Helenistik-Roma dönemlerine ait kent dokusu içinde yeni sokaklar, kenti güneyden çevreleyen sur duvarları, bunun bir kapıs1, hendekler, su boruları (künk), ocak yerleri, mezarlar belirlenmiştir. ${ }^{13}$

Veriler üzerindeki değerlendirmelerden sonra 2006 yılında yapılan G 27 kazısında savunma hendeğinin doğu uzantısındaki bir bölümü açığa çıkarılmıştır (Fig. 6). Burada açmanın üst seviyelerinde Helenistik-Roma çağlarına ait kent yapıları ve bir sokak belirlenmiștir. Sokağın altında bulunan hendek anakayaya kazılarak yapılmış olup, $4 \mathrm{~m}$ genişlik, 1,6 m derinliktedir. Doğal eğime uygun olarak batı kenarı $0,5 \mathrm{~m}$ daha yüksektir. Hendek bol çanak çömlek kırıkları, hayvan kemikleri, odun kömürü kırıntıları, yanmış kerpiç parçaları ve çeşitli büyüklükte taş parçaları içeren gri, ince kumlu bir dolgu ile dolu olup, çanak çömlek parçalarından çoğunun Troya VI dönemine ait olduğu belirlenmiştir. Çevre ile yapılan karşılaştırmalara göre hendeğin Troya VI sonu veya hemen sonrasında dolduğu varsayılmaktadır. ${ }^{14}$

11 Korfmann 2001: 1-50.

12 Korfmann 2001: 27.

13 Hübner ve Giese 2006: 125.

14 Jablonka ve Pernicka 2007: 3-24. 
G 27 karesinde yapılan kazıda hendeğin kuzeydoğuya yönelerek devam ettiğinin görülmesi üzerine, 2007 yılında İç Kale doğusunda 2,4 hektarlık bir alanda yeni jeofizik ölçümler yapılmıştır. Daha önce "Fluxgate Magnetometer" ile yapılan ölçümler bu defa "Caesium Magnetometer" kullanılarak tekrarlanmış, ayrıca G 27 kazısı kuzeyinde "Ground Penetrating Radar" yöntemi ile $6000 \mathrm{~m}^{2}$ lik alan taranmıştır. Radar ölçümünde saptanan silik bir anomalinin hendeğin devamı olabileceği düşünülerek M-P 18 kareleri boyunca kepçe ile kazılar yapılmış (Fig. 6), Fakat burada hendek izine rastlanmamıştır. ${ }^{15}$

Savunma hendeğinin kuzey veya kuzeydoğuya devamını belirlemede, mümkün olan tüm yöntemleri denemiş olmak için, son olarak 2008 yılında, G 27 karesi kuzey ve kuzeydoğusunda "Geoelectric 2D Tomography" ölçümleri ile toplam 11 profil çıkarılmıştır. Bu profillerde kültür tabakası altındaki anakaya yüzeyi ve bu yüzeyde hendek uzantısı olabilecek bazı çukurluklar belirlenmiştir. Özellikle jeofizik verilerin G 27 karesindeki açmada ortaya çıkan hendek uzanımı ile uyumlu bulunduğu dikkati çekmiştir. Ancak tüm bu çalışmalarda savunma hendeğinin kuzey veya kuzeydoğuya uzandığını net olarak gösteren bir veri bulunamamıştır. Sonuç olarak, G 27 karesinde açılan hendek uzanımının kuzeydoğuya dönüyor görünmesinin doğrulanabilmesi için yeni araştırma ve kazılar yapılması önerilmiştir. ${ }^{16}$

\section{Delgi sondaj çalışmaları}

Troya VI (Geç Tunç Çağı) savunma hendeğinin doğudaki uzanımı ile ilgili olarak jeofizik ölçümlerden sağlanan yüzey altı bilgileri ve hendeğin G 27 karesindeki kazılarla açığa çıkarılan uzanımı dikkate alınarak, 2008 y1lında, yeni bir araştırma aşaması olarak, kazı alanını doğudan çevreleyen tel çitin batı kenarinda (K 25) arkeologlarca Unimog ile bir dizi sondaj çalışması yapılmıştır (Fig. 6: 2008-1). Ancak, yukarıda belirtildiği gibi, bu yöntemde özellikle kuru zeminde tüm materyal (taşlar ve ince dokulu ara dolgusu) öğütülürcesine ufalandığ 1 ve karıştı̆g 1 için sonuç alınamamıştır.

15 Jablonka ve Pernicka 2009: 10-16.

16 Jablonka ve Pernicka, 2007: 6; Jablonka ve Pernicka 2009: 5.
Ekibimiz bu aşamada çalışmalara katılmış, çakma-delgi yöntemiyle sondajlara devam edilmiștir. Hendek uzanımının geçtiği varsayılan doğrultu üzerinde, bu doğrultuya dik olarak yapılan delgi sondajlarla, öncelikle yüzey örtüsü altındaki anakaya yüzeyinin profili çıkarılmaya çalışılmıștır. Hendek olabilecek bir çukurluğun bulunması durumunda, karot içinde kültürel materyal (özellikle Tunç Çağına ait çanak çömlek parçaları gibi) de gelmişse, arkeologlarla bir değerlendirme yapılmış, uygun görüldüğünde kazı çalışmalarına geçilmiştir (Fig. 3, 6, 7).

Ekibimizin ilk çalışmasında, Unimog ile K 25 karesinden kuzeybatıya doğru yapılan, fakat sonuç alınamayan profilin tamamlanması amaçlanmıştır (2008-1: Fig. 6, 7, 8). Bu alanda 2-3 m kadar aralıklarla yapılan 24 delgide, yüzeydeki $50 \mathrm{~cm}$ 'yi geçmeyen güncel organik toprak altında, genellikle mimari yıkıntılara ait taş blokları ve aralarını dolduran ince dokulu dolgudan oluşan bir örtünün varlığ 1 belirlenmiştir. Bunun içinde yer yer çokça kiremit ve çanak çömlek kırıkları ile küçük yanık artıkları (kömürleşmiş küçük ahşap veya bitki parçaları, siyahlaşmış küçük çanak çömlek k1rıntıları) bulunmuştur. Birkaç metre kalınlıktaki bu örtünün altında Neojen (Üst Miosen) anakayanın kireçli, killi, kumlu güneye çok az eğimli tabakalarına girilmiştir. Burada, yüzeydeki küçük ölçülü arızalılık, hendek uzantısının ayırt edilmesini zorlaştırmıştır. Bununla birlikte, profilin kuzeybatısındaki 18. delgide 5 metreye kadar inilebilmiş, burada anakayayanın üzerindeki dolguda, taş bloklar arasında küçük çanak çömlek kırıkları ile yanık kırıntılar bulunmuştur. Buna göre, bizce buranın hendek uzantısı olduğu düşünülmüş, ancak dolguları inceleyen arkeologlar bu çukurluğun hendekle ilgisi olmadığı değerlendirmesini yapmışlardır (Fig. 8).

Bunun üzerine, bu profilin $200 \mathrm{~m}$ kadar kuzeydoğusunda, yine KB-GD doğrultusunda uzun bir çizgi boyunca Unimog ile yapılan delgilerin, ortada hendek uzantisina daha uygun olduğu düşünülen bölümü 5 çakma delgi ile tamamlanmıștır (Fig. 6: 2008-2). Burada da yüzeyi kaplayan örtü altında, 2-3 m derindeki anakaya yüzeyinde $1 \mathrm{~m}$ kadar arızalılık belirlenmiştir. Özellikle profilin güneydoğu kesimindeki çukurluk, silik bir hendek 
profili şeklinde belirmiştir (Fig. 9). Ancak, arkeologların buradaki değerlendirmeleri de çukurluğun hendekle ilgisi bulunmadığı yönünde olmuştur. Sonuç olarak arkeologlar, 2007 yılında M-P 18 karelerinde yapilan kepçe kazıları ile 2008-1 ve 2008-2 profillerinde, birkaç metrelik yüzey örtüsü altında, anakaya yüzeyinde belirlenen arızalılık içinde hendeğin devamının bulunmadığını, hendeğin 2008-1 profili kuzeyinde devam etmediğini varsayarak çalışmalarını G 27 açması ile 20081 profili arasındaki alanda yoğunlaştırmışlardir (Fig. 6, 7).

G 27 karesinde açığa çıkarılan hendek bölümünün 20 m kadar kuzeydoğusundaki 20083 profil çalışmasında toplam 14 çakma-delgi sondaj yapılmıștır (Fig. 7, 10). Bunların çoğunda taşlardan ilerlemek mümkün olmamış, anakayaya ulaşmak için gereken derinliğe inilememiștir. Bununla birlikte, geçilemeyen taşların anakayadan farklılığ ve çeşitliliği, bunların yüzey dolgusu içindeki yıkıntı (mimari) taşlarına ait olduğunu göstermiştir. $\mathrm{Bu} \mathrm{du}$ rumda, zorunlu olarak sondaj noktaları profil çizgisi dışında alana yayılmış, bu sayede orta kesimdeki 10 ve 13 numaralı delgilerde $5 \mathrm{~m}$ kadar derinlere inilebilmiş ve anakayaya ulaş1 1 ış̧tır. Bu bilgiler 1şığında, arkeologlarca $\mathrm{H}$ 26 karesinde kazı yapılmış, belirlenen çukurluğun gerçekten hendeğe ait olduğu görülmüş ve hendeğin kuzeydoğu uzantısı üzerinde bir bölümü daha açı̆ga çıkarılmıştır (Fig. 7). Burada anakaya ile yüzey örtüsündeki yapı kalıntısı taşların litolojik farklılığının dikkate alınması hendeğin saptanmasında etkili olmuş, deneyim kazandırmıştır.

2008 yılında, H 26 karesindeki kazıdan sağlanan bilgilerle arkeologlar bunun 20 m kadar kuzeydoğusunda H-I 26 kazısını yapmışlar ve burada da hendeğin bir bölümünü açığa çıkarmişlardır (Fig. 7). Ancak burada hendeğin son buluyor görünümü şaşırtıcı olmuştur. Bunun üzerine hendeğin doğuya doğru devam etme (doğuya doğru dönüyor olma) ihtimali üzerinde durulmuş ve 2009 yılında I-K 25 karesinde (tel çitin batı yanında) arkeolojik kazı yapılmaya bașlanmıștır. Bu aşamada ekibimiz tarafından I-K 24-25 alanında 10 çakma delgi sondaj yapılmış, sağlanan verilere göre oluşturulan bat1-doğu doğrultulu 2009-1 profili (Fig. $6,7,11)$ üzerinde hendek çukurluğu net olarak görülmüş̧tür. Buna dayanılarak söz konusu alanda yapılan arkeolojik kazıyla da bu bulgu doğrulanmıştır. Burada anakayaya kazılmış olan hendeğin genişliği 4,2 m olup, kenarları diktir. Hendek derinliği doğal yüzey eğimine uygun olarak kuzeybatı kenarda 1,5 m, güneydoğu kenarda $1 \mathrm{~m}$ kadardır. Hendek içinde Geç Tunç Çağına ait kültürel materyal (çanak çömlek kırıkları) içeren kolüvyal nitelikli bir dolgu bulunmuştur.

2009 y1lında, 2009-1 profili üzerinde hendek çukurluğunun tespit edilmesi üzerine, 2008 yılında yapılan H-I 26 kazısı 2009 ve 2010 yıllarında kuzey ve kuzeydoğuya doğru genişletilmiştir. Açılan bölümde (H-I 25-26) hendeğin son bulmadığ 1 , burada, güneyde z 29-A 29 karelerindekine (Fig. 3) benzer şekilde, $5 \mathrm{~m}$ genişlikte bir geçit bulunduğu belirlenmiştir. Böylece, ilk açılan bölümde geçidin güney kenarının hendeğin son bulduğu şeklinde yanlış değerlendirildiği anlaşılmıştır (Fig. 7). Geçidin güney kesiminde, hendek dolgusu içinde Troya VI dönemine ait çanak çömlek kırıklarının bulunması hendeğin bu döneme ait olduğunun kanıtları arasında değerlendirilmiştir. Kuzey kesimde de benzer özelliklerde devam eden hendeğin, toprakla karışık Geç Tunç Çağına ait kültürel birikintilerle dolu olduğu belirlenmiştir. Öte yandan geçit çevresindeki dolgularda çok miktarda büyük baş hayvan kemiklerinin bulunması, geçit kullanımı ile ilişkilendirilmiştir. ${ }^{17}$

2009 yılında, I 25 karesindeki geçidin kuzeydoğusunda Troya Geç Tunç Çağı savunma hendeğinin uzanımını belirleme çalışmalarına devam edilmiştir. I-K 24-25 alanında yapılan 10 çakma delgi sondaj verilerine göre oluşturulan bat1-doğu doğrultulu 2009-1 profili (Fig. $6,7,11)$ üzerinde hendek çukurluğu net olarak görülmüş ve yapılan arkeolojik kazıda bu bulgu doğrulanmıştır. Burada anakayaya kazılmış olan hendeğin genişliği 4,2 m olup, kenarları diktir. Hendek derinliği doğal yüzey eğimine uygun olarak kuzeybatı kenarda $1,5 \mathrm{~m}$, güneydoğu kenarda $1 \mathrm{~m}$ kadardır. Hendek içinde Geç Tunç Çağına ait kültürel materyal (çanak çömlek kırıkları) içeren kolüvyal nitelikli bir dolgu bulunmuştur.

17 Jablonka vd. 2011: 7-42. 
2009-1 proilinin 20 m kadar kuzeyindeki 20093 profili 13 delgi ile oluşturulmuștur (Fig. 6, 12). Yüzey örtüsündeki enkaz taşları nedeniyle profil çizgisinden sapmalarla tamamlanabilen çalışmada, diğerlerine benzer şekilde 2-3 metrelik yüzey örtüsü altında anakayaya girilmiștir. Burada 1 m’ye yakın bir çukurluk belirlenmekle birlikte, arkeologlar bunu hendek uzantısı olarak değerlendirmemişlerdir.

2009-3 profilinin $40 \mathrm{~m}$ kadar kuzeydoğusundaki 2009-2 profili 18 delgi ile oluşturulmuştur. Burada da benzer özelliklerdeki örtü altında, anakaya yüzeyinde yaklaşık 1 metrelik arızalılık bulunmaktadır (Fig. 6, 13). Buradaki arızalılık içinde de hendek uzanımıyla ilişsilendirilebilecek bir çukurluk dikkati çekmemiştir. Esasen, arkeologlar 2009-1 profilimiz üzerinde açılan I-K 2425 kazısı kuzeydoğusunda hendeğin devam etmediği veya sonraki zamanlarda tahrip edildiği yönünde bir değerlendirme ile 2008 yılından sonra bu alandaki çalışmalarına son vermişlerdir.

Bununla birlikte, bu kesimde hendeğin kuzeye doğru yönelerek iç kaleye bağlanma ihtimali düşünülmüş, bunu araştırmak amacıyla ekibimizce 2011 y1lında toplam 25 delgi yapılmıştır. Bunlar da tek bir profil olarak planlanmış, ancak yüzey örtüsündeki taşlardan ilerlenemediği için orta kesimde paralel kaydırma yapılmıştır. Burada da özellikle doğu kesimde anakaya yüzeyindeki arızalılık dikkati çekmiş, ancak yine arkeologlarca hendekle ilișkili görülmeyerek üzerinde durulmamıştır (Fig. 6, 14).

2010 yılında Troya girişindeki düzenlemeler ve otopark alanının zemin kaplaması için yapılan çalışmaların yüzey altında neleri örteceğinin belirlenmesi amacıyla farklı bir delgi sondaj çalışmasına başlandı. Otopark güneyinde yaklaşı 100 m'lik bir çizgi boyunca $2 \mathrm{~m}$ aralıklarla 57 delgi sondaj yapıldı (Fig. 6, 15). Bu delgilerde genellikle 2,5-3,0 $\mathrm{m}$ kadar derinlikte anakayaya girildi. Bunun batı kesimindeki 32 delgide 50-70 cm kadar bir kültür tabakası saptand. Anakaya yüzeyini kaplayan bu yayıntı koyu renkli, toprağımsı bir dolgu ile çokça küçük yanık unsurlar, çanak çömlek kırıntıları, seyrek olarak da küçük kemik parçaları karışımından oluşmaktadır. İçinde prehistorik materyalin de bulunduğu bu yayıntıyı, arkeologlar daha çok MÖ 85 yılında olduğu bilinen kentteki yıkımla ilişkilendirmişler ve önemli bir yeni buluntu olarak değerlendirmişlerdir.

Otopark güneyindeki uzun profil 2011 yılında 23 delgi sondaj ile batıya doğru $60 \mathrm{~m} \mathrm{ka-}$ dar daha uzatıldı. Böylece 80 delgiden oluşan ayrıntılı profilde, yüzeydeki 3 m'yi geçmeyen, ince dokulu, fakat yer yer iri taşlar da içeren örtü altında, oldukça düzgün uzanışlı anakaya yüzeyine ulaş1lmıştır (Fig. 6, 15). Güncel topoğrafyaya uygun olarak anakaya yüzeyindeki çok hafif eğim (\%015 kadar), Neojen tabakaları üzerinde, yapıya (tabaka yüzeyine) uygun bir düzlük olduğunu göstermektedir. Öte yandan, Troya'da her yerde görüldüğü gibi, burada da arkeolojik kültür-enkaz örtüsü doğrudan anakaya yüzeyine yayılmaktadır. Bu veri, daha önce Troya yerleşim alanının başka kesimleri için belirlenen özelliğe uygun olarak, Tunç Çağı insanlarının toprak örtüsünden yoksun, çıplak bir kayalık yüzey üzerine yerleştiklerini göstermektedir. ${ }^{18}$

Tunç Çağ 1 Troya savunma hendeğinin kuzeydoğuya devamını araştırma çalışmalar1 kapsamında, 2010 yılında bir yoklama da Troya girişindeki otoparkın güneydoğu köşesinde yapıldı. Burada Unimog delgileriyle anakaya yüzeyinde bir çukurluk belirlenmiş, bunun hendeğin uzantısı olup olmadığının araştırılması istenmişti. 2011 yılında bu alanda yaptığımız 15 delgi sondaj (Fig. 6, 16) ile bu çukurluğun $3 \mathrm{~m}$ kadar örtülü anakaya üzerinde 6-7 m'ye kadar inen doğal bir yüzey arızas1 olduğu anlaşılmıştır. Otopark güneyindeki yanıklı ince enkaz yayıntısının buradaki çukurlukta dolgu olarak bulunması dikkatimizi çekmiş, ancak prehistorik materyal içermeyen bu dolgunun, Helenistik-Roma dönemleri kentinin (İlion) tahribinden sonra, yüzeysel sürüklenmeyle burada biriktiği değerlendirmesi yapılmıştır. Sonuç olarak burada da hendekle ilgili somut bir veri bulunmamıştır.

2008 yılında bir delgi sondaj profil çalışması da (2008-4), farklı bir alanda, Troya İç Kalesinin $500 \mathrm{~m}$ kadar doğusunda, FF 6 karesinde yapılmıştır (Fig. 3, 17). Burada amaç, daha önce jeofizik araştırmalarla belirlenen bir anomalinin, güneydeki hendeğin doğudan dolaşarak iç kaleye bağlandığ 1 anlamına gelme olasılığını aydınlatmaktı. Yine KD-GB doğrultulu bir

18 Kayan 1997: 489-507. 
çizgi üzerinde 7 delgiden oluşan profilde ince bir yüzey örtüsü altında hendek izine rastlanmamıștır. Manyetik anomalinin nedeninin, 3. delgide $80-110 \mathrm{~cm}$ derinde bulunan pişmiş topraktan bir su borusu (künk) olduğu anlaşılmıştır. Bu da, jeofizik anomalilerin delgi sondajlardan sağlanacak bulgularla birlikte değerlendirilmesinin önemini gösteren bir deneyim olmuştur.

\section{Tartışma ve Sonuç}

Tunç Çağı Troya savunma hendeği üzerinde bugüne kadar yapılan, birbiri ile ilişkili jeofizik araştırmalar, delgi sondajlar ve arkeolojik kazılar, hendeğin Așağı Kenti güneyden çevrelediğini, doğuda kuzeydoğuya dönerek uzandığını göstermiştir. 2006-2011 yılları arasında hendeğin doğudaki uzanımını belirlemek için yapılan yoğun araştırmalarda ise H-I 25-26 karelerinde hendek üzerinde bir geçidin bulundu$\breve{g} \mathrm{u}$, buradan hendeğin kuzeydoğuya devam ettiği görülmüş, ancak I-K 24-25 kareleri kuzey veya kuzeydoğusunda hendek izlenememiştir (Fig. 3, 6, 7). Bu doğrultularda, daha ilerilerde yapilan yoklamalarda da kentin doğusunda hendeğin devam ettiğine dair bir iz bulunamamıştır. Buna göre, arkeologların önceleri düşündüğü gibi, hendeğin doğudan dolaşarak İç Kaleye bağlanmasının mümkün olmadığ 1 anlaşılmıştır. Arkeolojik bakımdan hendek uzanışının bir önemi veya anlamı da Aşağı Kentin büyüklüğünün, dolayısıyla kent nüfusunun belirlenmesine esas oluşturmasıdır. Ancak, doğuda hendek uzanışının belirlenememesi bu konudaki beklentinin sonuçsuz kalmasına neden olmuştur.

Hendek uzanışı ile ilişkili olarak göz önünde bulundurulması gereken diğer bir husus da H-I 25-26 kazılarıyla açığa çıkarılan hendek üzerindeki geçittir. Hendeğin bunun kuzeydoğusunda da devam ettiği 2009-1 profilimiz ve buradaki I-K 24-25 kazısında belirlenmiş, ancak daha ileriye uzanımı izlenememiştir (Fig. 6, 7, 11). Kuşkusuz, hendeğin bitmek üzere olduğu yerde geçit bırakılmasının anlamı yoktur ve hendeğin geçitten sonra kuzeydoğuya epeyce devam etmesi beklenmelidir. Bu uzantının bulunamamas1, arkeologlarca hendeğin burada sona erdiği veya daha kuzeydoğudaki uzant1sının sonraki zamanlarda tahrip edildiği şeklinde yorumlanmıştır. Troya binyıllar boyunca tekrar tekrar yıkılmış ve yeniden inşa edilmiş bir kenttir. Bunun için her yenilenmede önceki yıkıntı taşlarının kullanılması yanında, çevredeki uygun yerlerden taş alınması, böylece hendek profilinin tahrip edilmiş olması beklenebilecek bir olasıliktır. Ancak bununla ilgili bir kanıt bulunmamaktadır.

Arkeologların ilgisini çekmese de, bizim I-K 24-25 kazısı kuzeydoğusunda oluşturduğumuz 2009-3, 2009-2, 2011-3, 2008-2 profillerimizde, anakaya yüzeyinin silik ve düzensiz bir arızalılığ1 içinde izlenebilen bir çukurluğun varlığ1 dikkatimizi çekmişstir (Fig. 12, 13, 14, 9). Bu zon güneybatıda kesin olarak belirlenen hendek çukurluğuna (I-K 24-25: 2009-1) çok yaklaşmakta, fakat onunla birleșmemektedir (Fig. 6, 8). Kuzeydoğuda ise 2011-1 profilindeki çukurluğa bağlanması, arkeolojik bakımdan uygun görülmese de uzanım bakımından uyumluluğu dikkati çekmektedir (Fig. 6, 16).

Troya Aşağ 1 Kentini çevreleyen hendeğin bütününde, fakat özellikle üzerinde durulan güneydoğu kesiminin uzanışında Troya sirtının jeolojik yapısı ve bununla uyumlu jeomorfolojisinin göz önünde bulundurulması gerekir (Fig. 18). Troya sirtı Neojen (Üst Miosen) sığ deniz ortamında birikmiş kireçli, killi, kumlu, yer yer çakılll, genellikle $50 \mathrm{~cm}$ 'yi geçmeyen kalınlıktaki tabakalardan oluşmaktadır. $\mathrm{Bu}$ formasyon, sonraki yer kabuğu hareketleri ile bloklar halinde parçalanmış, bunlardan bazıları değişik doğrultularda hafif eğimlenerek yükselmiştir. Yükselen bloklar bugün 50 $\mathrm{m}$ kadar yüksekliklerde izlenen alçak plato sırtlarını (Kumkale, Troya, batıda Yeniköy) oluşturmuştur. Bunlar arasındaki çöken bloklar üzerinde ise akarsuların buralara yönelmesi ile alüvyal vadi tabanı düzlükleri (Karamenderes, Dümrek) şekillenmiştir. Troya sırt1, hafifçe güneydoğuya eğimlenerek yükselen tabakalardan oluşmuştur. Bu nedenle Dümrek vadisine bakan kuzey yamaçlar dik, Çıplak vadisine inen güney yamaçlar az eğimlidir ${ }^{19}$ (Fig. 18).

Gözleme dayanan diğer bir bilgimiz de Troya yerleşmesinin ilk aşamalarında (Tunç Çağı) toprak veya ayrışmış bir yüzey örtüsü bulunmayan, çılak bir kayalık yüzey üzerinde kurulduğudur. Böyle bir yüzeyin kenarlarında,

19 Kayan 1996: 239-249; Kayan 1997: 489-507; Kayan 2019: 277-291. 
az eğimli tabaka başları (alınları) litolojik özelliklerine ve tabaka kalınlığına uygun, dik basamaklar oluşturabilir. Aşınmaya karşı fark11 dirençteki tabakalardan daha kireçli olanlar (kireçtaşı, marn) daha dik alınlar, basamaklar; daha dirençsiz olan killi-kumlu tabakalar daha yumuşak profilli, silik basamaklar oluşturur. Buna göre, Troya Aşağı Kent güney ve güneydoğu çevresinde savunma hendeği yapılırken, uygun yerlerde anakaya yüzeyinin doğal arızalılığından (tabaka basamakları) yararlanılmış olabilir. Öte yandan, doğuda hendek uzantısında bir tabaka basamağı, savunma hattının devamı olarak hendek yerine kullanılmış da olabilir. Bizim 2009-3 ve kuzeyindeki profillerimizde izlenen hendek benzeri çukurlukların anakaya yüzeyinde bir kireçtaşı tabaka basamağı ile ilişkili olabileceğini düşünüyoruz (Fig. 6, 19). Burada dik bir tabaka alnı önündeki alanda aşınma ile kopan iri kaya bloklarının bulunması ve bunun da sondajlarda belirlenen anakaya yüzey arızalıl1ğını artırması doğaldır. Ayrıca, bu alanın Tunç Çağ1 ve sonrasında, tabaka alınlarından taş bloklarının alınmasıyla taş ocağı olarak kullanılmış olabileceği de düşünülebilir. Ancak bunları belirleyecek verileri sağlamanın kolay olmaması, asıl amaç olan hendek uzanımı ile ilgili somut veriler bulunamaması nedeniyle bu alandaki çalışmalara son verilmiştir.

Günümüzde Troya Aşağı Kent alanını kaplayan ve güneydoğuda yoğun çalışılan alanda birkaç metre kalınlıkta olan yüzey örtüsü, bütünüyle Troya enkazından oluşmaktadır. Örtünün toprak görünümlü ince unsurları da büyük ölçüde yapıların yıkılan kerpiç duvarlarının dağılmasyyla oluşmuştur. Kuşkusuz, bu örtünün kentin terk edilmesinden sonra geçen binlerce y1ll1k sürede doğal toprak oluşum süreçleriyle kısmen değişime uğradığını, yüzeyde 0,5 m'yi geçmeyen bir organik toprak katmanının oluştuğunu da göz önünde bulundurmak gerekir. Yüzey örtüsünün bir unsuru da MÖ 85 y1lına tarihlenen kentteki büyük yangınlı yıkımın, daha sonra yağmur suları ile yıkanarak yüzeye yayılan ince taneli enkaz yayıntısıdır. Daha düz uzanışlı kent alanına yayılan bu örtünün, az eğimli yamaçlardan aşağılara yüzey suları ile yıkanarak taşındığı ve çukurluklarda biriktiği anlaşılmaktadır. Önceki delgi sondajlarımızda, Aşağı Kentin özellikle güney ve güneydoğu çevresinde bu ince taneli yayıntıya birçok yerde rastlanmıştır. ${ }^{20}$ Otopark güneyine de belirlenen bu yayıntının, daha doğuda 20111 profilindeki çukurlukta kalınca bir dolgu şeklinde biriktiği söylenebilir.

Sonuç olarak Troya Aşağı kent savunma sisteminin kalıc1 ve izlenebilir unsuru olan hendek üzerinde çok durulmasının, uzanışı ile ilgili yoğun araştırmalar yapılmasının çok yönlü nedenleri bulunmaktadır. Bu çalışmalara, pek çok Unimog delgiden başka, toplam sayısı 201 i bulan çakma-delgi sondajlarla doğrudan katkımız olmuştur. Öte yandan, hendek uzanışı ile ilgili değerlendirmelere, bu alanda ve yakın çevresinde yaptığımız jeolojik-jeomorfolojikpaleocoğrafik araştırmalardan sağlanan bilgilerle interdisipliner bir nitelik kazandırılmıştır. Çalışmanın amaç, yaklaşım ve uygulama bakımından özgün bir jeoarkeolojik araştırma örneği olduğu görülerek, bu örneğin bu yayınla tanıtılmasının yararlı olacağı düşünülmüştür.

\section{Teşekkür}

Troya VI savunma hendeğinin Aşağı Kent doğusundaki uzanımı ile ilgili yoğun araştırmalara katılımımız Prof. Dr. Ernst Pernicka ve Dr. Peter Jablonka'nın davet ve yönlendirmeleri ile gerçekleşti. Prof. Dr. Rüstem Aslan ve Dr. Sinan Ünlüsoy, yakın ilgi ve destekleri, bulgularımızın arkeolojik yorum ve değerlendirmeleri ile çalışmalarımıza büyük katkı sağladılar. Sayın Aslan yazımızı okuyarak arkeoloji bilgilerinde hatamız olmaması için katkıda bulundu. Çalışmalarımız Troya Kazı Kampının bilimsel ortamında, Türk ve misafir bilim insanlarının yakın ilgi ve destekleri ile sürdü. Hepsine teşekkürlerimizi sunuyoruz. Yeni dönem Troya Arkeolojisinin lideri Prof. Dr. Manfred Osman Korfmann'1, jeofizik çalışmalarına büyük emek veren Dr. Hans Günter Jansen'i ve bu yıl kaybettiğimiz Dr. Peter Jablonka'yı saygıyla anıyoruz. Troya çalışmalarının bütününe büyük katkısı olan Jablonka, hendek çalışmalarına da çok önem verdi; çalışmalarımızın arkeolojik değerlendirmeleriyle ilgili ayrıntılı yayınlar yaptı. Sondaj çalışmalarımıza katılan ögrencilerimiz Senem Yıldız ve Ertan Kalkan'a da teşekkür ederiz.

20 Kayan 1997: 489-507. 


\section{KAYNAKÇA}

Becker 1993: H. Becker, J. Fassbinder, H.G. Jansen, "Magnetische Prospektion in der Untersiedlung von Troya 1992”, Studia Troica, Band 3, 117-134.

Becker ve Jansen 1994: H. Becker, H.G. Jansen, "Magnetische Prospektion 1993 der Unterstadt von Troya und Ilion”, Studia Troica, Band 4, 105-115.

Blindow vd. 2000: N. Blindow, H.G. Jansen, K. Schröer, "Geophysikalische Prospektion 1988/99 in der Unterstadt von Troya", Studia Troica, Band 10, 123-133.

Hübner ve Giese 2006: C. Hübner, S. Giese, "Geophysikalische Prospektion 2002 bis 2005 in der Unterstadt von Troia", Studia Troica, Band 16, 125-129.

Jablonka vd. 1994: P. Jablonka, H. König, S. Riehl, "Ein Verteidigungsgraben in der Unterstadt von Troya VI. Grabungsbericht 1993”, Studia Troica, Band 4, 51-73.

JABLONKA 1995: P. Jablonka, "Ausgrabungen südlich der Unterstadt von Troya im Bereich des Troya VI-Verteidigungsgrabens. Grabungsbericht 1994", Studia Troica, Band 5, 39-79.

JABLONKA 1996: P. Jablonka, "Ausgrabungen im Süden der Unterstadt von Troya. Grabungsbericht 1995", Studia Troica, Band 6, 65-96.

Jablonka ve Pernicka 2007: P. Jablonka, E. Pernicka, "Vorbericht zu den Arbeiten in Troya 2006 (Preliminary report on work at Troya 2006)", Studia Troica, Band 17, 3-24.

Jablonka ve Pernicka 2009: P. Jablonka, E. Pernicka, "Vorbericht zu den Arbeiten in Troya 2007 und 2008 (Preliminary report on work at Troya 2007 and 2008)", Studia Troica, Band 18, 3-32.

Jablonka vd. 2011: P. Jablonka, E. Pernicka, R. Aslan, "Vorbericht zu den Arbeiten in Troya 2009 und 2010 (Preliminary Report on Work in Troya 2009 and 2010)", Studia Troica, Band 19, 7-42.

Jansen vd. 1998: H.G. Jansen, T.L. Kienlin, A.E. Patzelt, M. Waldhör, J. Wilhelm, "Geophysikalische Prospektion 1996/97 in der Unterstadt von Troya", Studia Troica, Band 8, 275-284.

Jansen ve Blindow 2003: H.G. Jansen, N. Blindow, "The geophysical mapping of the Lower City of Troya/Ilion", In: Wagner G.A., Pernicka E., Uerpmann H-P. (Eds.), Troya and Troad. Scientific Approaches. Natural Science in Archaeology, 325-340.

JANSEN 2006: H.G. Jansen, "Das unsichtbare Troya sichtbar gemacht - Chancen und Ergebnisse der Anwendung neuer Prospektionsmethoden", In: Korfmann M.(Ed.) Troya. Archaologie eines Siedlungshügels und seiner Landschaf, Philipp von Zabern, 309-316.
KAYAN 1995: İ. Kayan, "The Troia bay and supposed harbour sites in the Bronze Age", Studia Troica, Band 5, 211-235, Philipp von Zabern, Mainz am Rhein, Germany.

KaYAN 1996: İ. Kayan, "Holocene stratigraphy of the Lower Karamenderes-Dümrek plain and archaeological material in the alluvial sediments to the north of the Troia ridge", Studia Troica, Band 6, 239-249, Philipp von Zabern, Mainz am Rhein, Germany.

Kayan 1997: İ. Kayan, "Geomorphological evolution of the Çıplak valley and archaeological material in the alluvial sediments to the south of the Lower City of Troia", Studia Troica, Band 7, 489-507, Philipp von Zabern, Mainz am Rhein, Germany.

KAYAN 2014: İ. Kayan, "Geoarchaeological research at Troia and its environs", Studia Troica, Monographien 5, (Troia 1987-2012: Grabungen und Forschungen I. Forschungsgeschichte, Methoden und Landschaft. Teil 2 (Herausgegeben von E.Pernicka, C.B.Rose, P.Jablonka), 694-727, Eberhard Karls Universitat Tübingen, Verlag. Dr. Rudolf Habelt GMBH. Bonn, Germany.

KAYAN 2019: İ. Kayan, "Landscape development and changing environment of Troia (North-western Anatolia)", In: C. Kuzucuoğlu, A. Çiner, N. Kazanc1 (Eds.), Landscapes and Landforms of Turkey, 277-291.

Korfmann 1993: M. Korfmann, "Troya-Ausgrabungen 1992”, Studia Troica, Band 3, 1-39.

Korfmann 1996: M. Korfmann, "Troya-Ausgrabungen 1995”, Studia Troica, Band 6, 1-64.

Korfmann 2001: M. Korfmann "Troya/Wilusa - Ausgrabungen 2000 (Troya/Wilusa - 2000 Excavations)", Studia Troica, Band 11, 1-50. 
Makale Gönderim Tarihi: 26.01.2021

Makale Kabul Tarihi: 22.02.2021

\section{ILHAN KAYAN}

Orcid ID: 0000-0002-8623-4101

ilhankayan11@gmail.com

\section{MEHMET DOĞAN}

Orcid ID: 0000-0002-3815-4203

Ege Üniversitesi, Edebiyat Fakültesi, Coğrafya Bölümü, Bornova/ İzmir.

mehmet.dogan@ege.edu.tr

\section{RİFAT İLHAN}

Orcid ID: 0000-0001-8392-9349

Adıyaman Üniversitesi, Fen-Edebiyat Fakültesi, Arkeoloji Bölümü, Adıyaman.

rifatcografya@gmail.com

\section{AYLIN KARADAŞ}

Orcid ID: 0000-0002-3845-3246

Ege Üniversitesi, Edebiyat Fakültesi, Coğrafya Bölümü, Bornova/ İzmir.

aylin.karadas@ege.edu.tr

\section{DOĞUKAN DOĞU YAVAŞLI}

Orcid ID: 0000-0002-0150-867X

Kırşehir Ahi Evran Üniversitesi, Fen-Edebiyat Fakültesi, Coğrafya Bölümü, Kırşehir.

dogukan.yavasli@ahievran.edu.tr

\section{RÜSTEM ARSLAN}

Orcid ID: 0000-0002-5304-1354

Çanakkale Onsekiz Mart Üniversitesi, Fen-Edebiyat Fakültesi, Arkeoloji Bölümü, Çanakkale.

rustemaslan@comu.edu.tr 


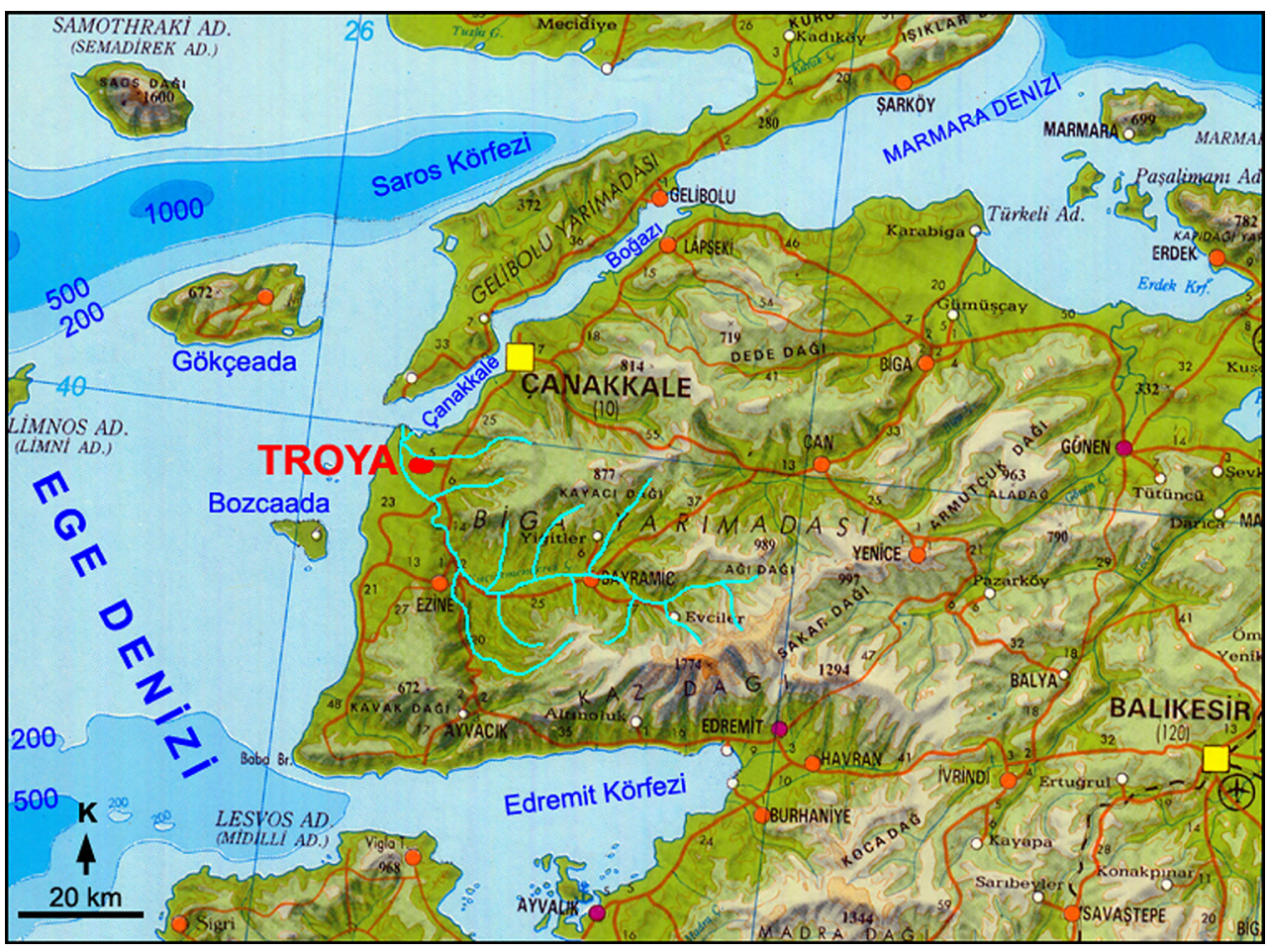

Fig. 1. Troya'nın coğrafi konumu. 1:1 000000 ölçekli Türkiye Fiziki Haritası'ndan (Harita Genel Komutanlığı) alınmış ve Karamenderes ırmağı belirginleştirilmiştir.

\begin{tabular}{|c|c|c|c|c|c|c|c|c|c|c|c|}
\hline NEOLITIK & KALKC & DLITIK & & $T \cup N C$ & C A G & L A R I & & DEMIR & CAGI & ROMA & BIZANS \\
\hline 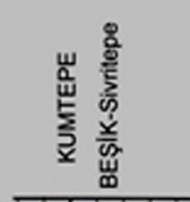 & 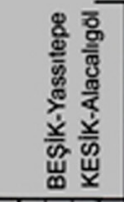 & $\begin{array}{l}\text { "TroiA } \\
\text { riden } \\
\text { daha } \\
\text { esket }\end{array}$ & & 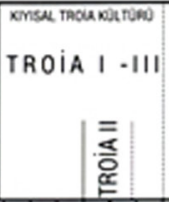 & 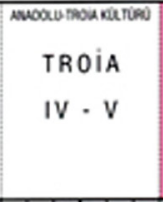 & $\begin{array}{r}\text { TrornotiA } \\
\text { VI } \\
\end{array}$ & 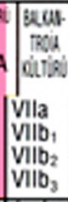 & 管 & $\begin{array}{l}\text { TROIA } \\
\text { VIII } \\
\text { (ILION) }\end{array}$ & $\begin{array}{l}\text { TROIA } \\
\text { IX } \\
\text { (iLION/ } \\
\text { iLIUM) }\end{array}$ & \\
\hline 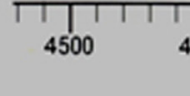 & $T_{4000}^{1} 11$ & $7_{3500}^{11}$ & \begin{tabular}{ll|l} 
& 1 \\
3000 & 1
\end{tabular} & LU & $\begin{array}{lll} & 1 & 1 \\
2000 \\
J V I\end{array}$ & \begin{tabular}{c|cc} 
& \\
1500 & 125 \\
Troya Sava
\end{tabular} & $\begin{array}{ll} & 1 \\
250 & 10 \\
\text { aşı ? }\end{array}$ & $\begin{array}{l}1 \text { I } \\
1000 \\
\text { Homer }\end{array}$ & $\left.{ }_{0 .}\right|_{500}|1| 1$ & $\pi_{85} \pi_{0} 11115$ & $\prod_{500} 11$ \\
\hline
\end{tabular}

Fig. 2. Troya kronolojisi. (Troya Kazı Arşivi ve Studia Troica yayınlarından düzenlenmiştir) 


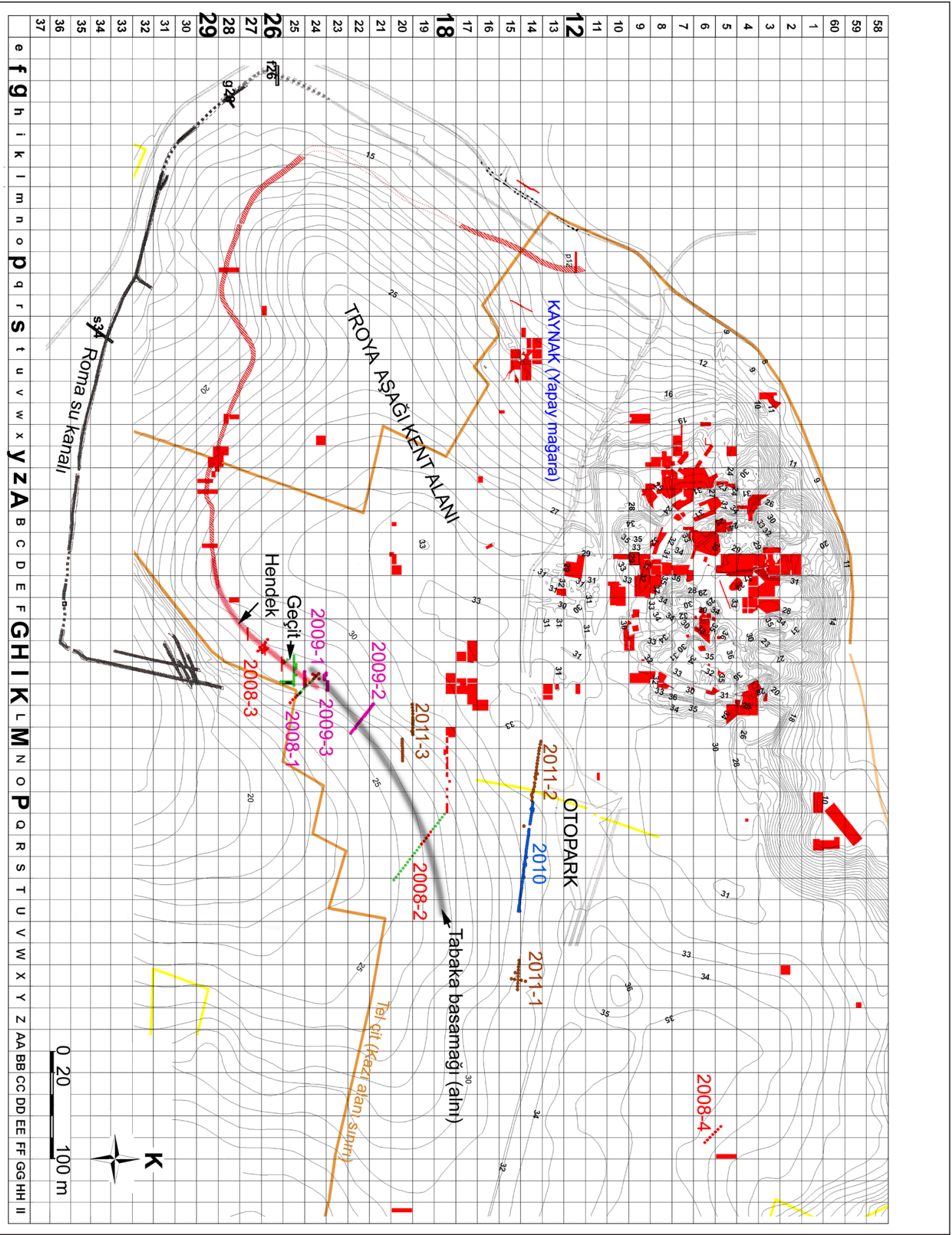

Fig.3. Troya kent planı ve kazı alanları (kırmızı dörtgenler). Güneydeki kırmızı çizgi Aşağı Kent alanını çevreleyen savunma hendeğinin jeofizik yöntemlerle belirlenen bölümüdür. Bunun doğudaki devamını belirlemek için farklı yöntemlerle yoğun araştırmalar yapılmıştır. Bunlardan bir bölümünü de bizim çakma-delgi sondaj çalışmalarımız oluşturmuştur.(Bkz. Fig. 4, 5). Çerçevedeki harf ve rakamlar Troya grid sistemini göstermektedir. (Altlık olarak kullanılan arkeolojik veriler Troya Kazı Arşivi ve Studia Troica yayınlarından alınmıştır: Korfmann 2001, Jablonka vd. 2011) 


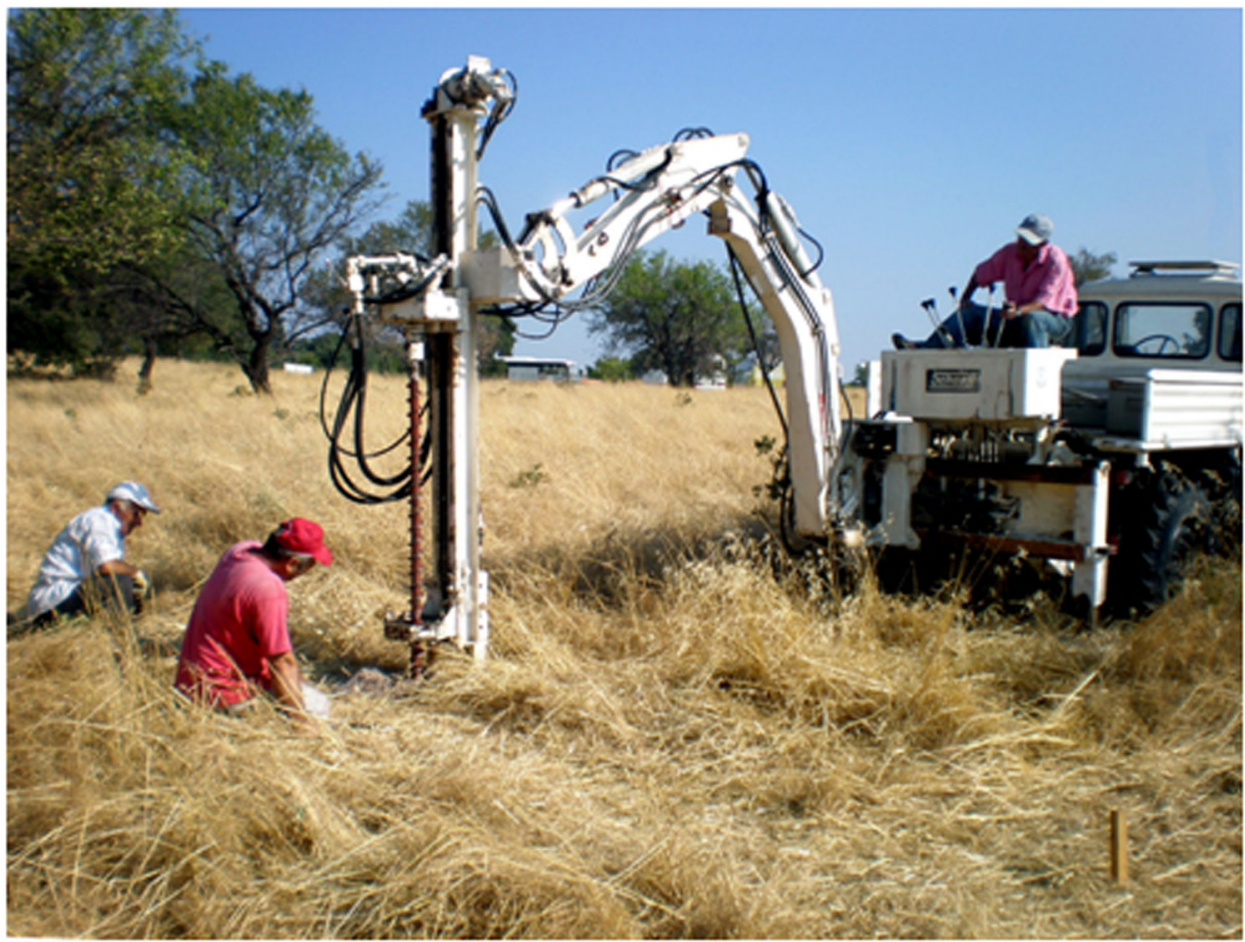

Fig. 4. Unimog iş makinesi ile yapılan burgu-delgi (auger drilling) çalışmaları.

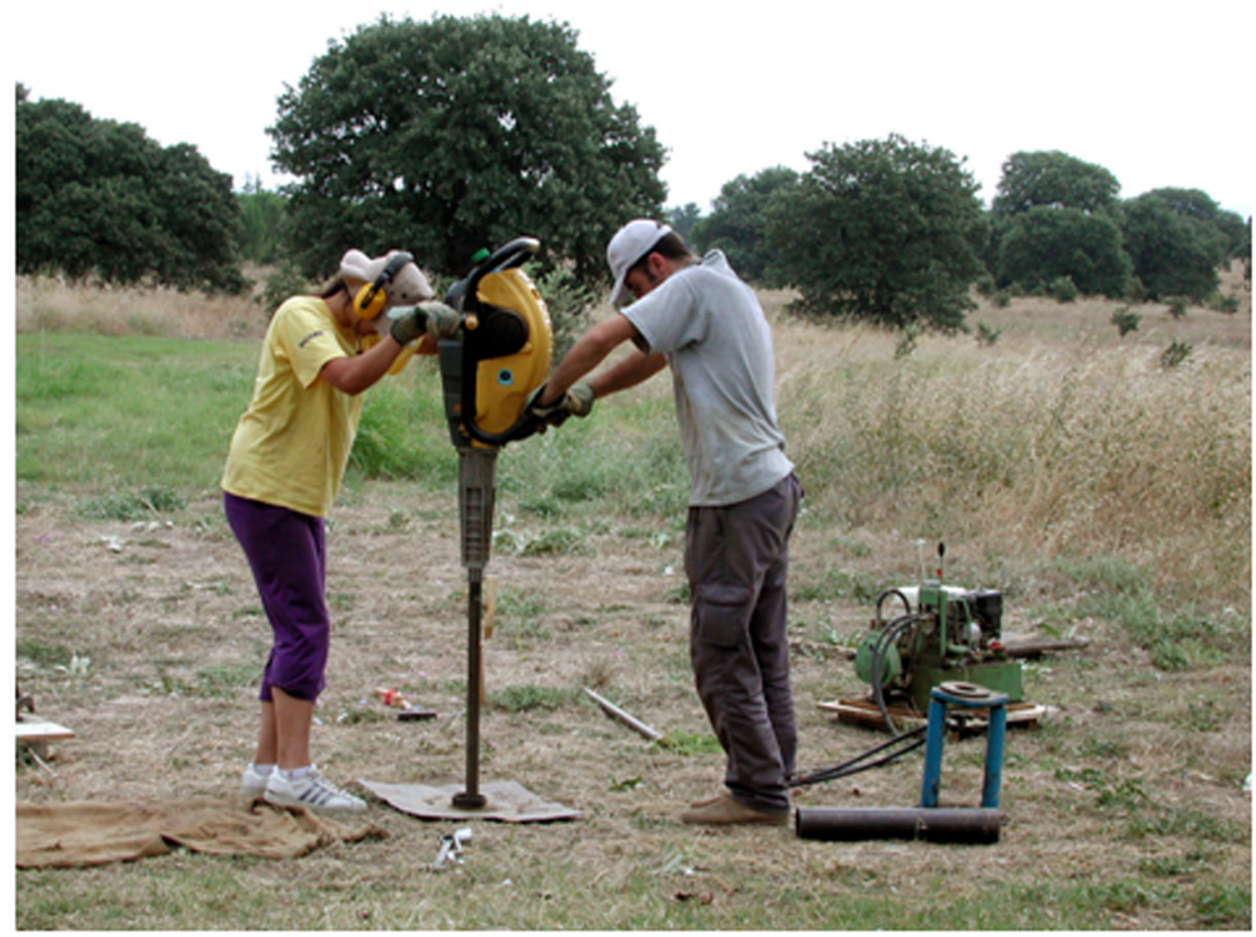

Fig. 5. Cobra delici ile yapılan çakma-delgi sondaj (percussion drilling) çalışmaları. 


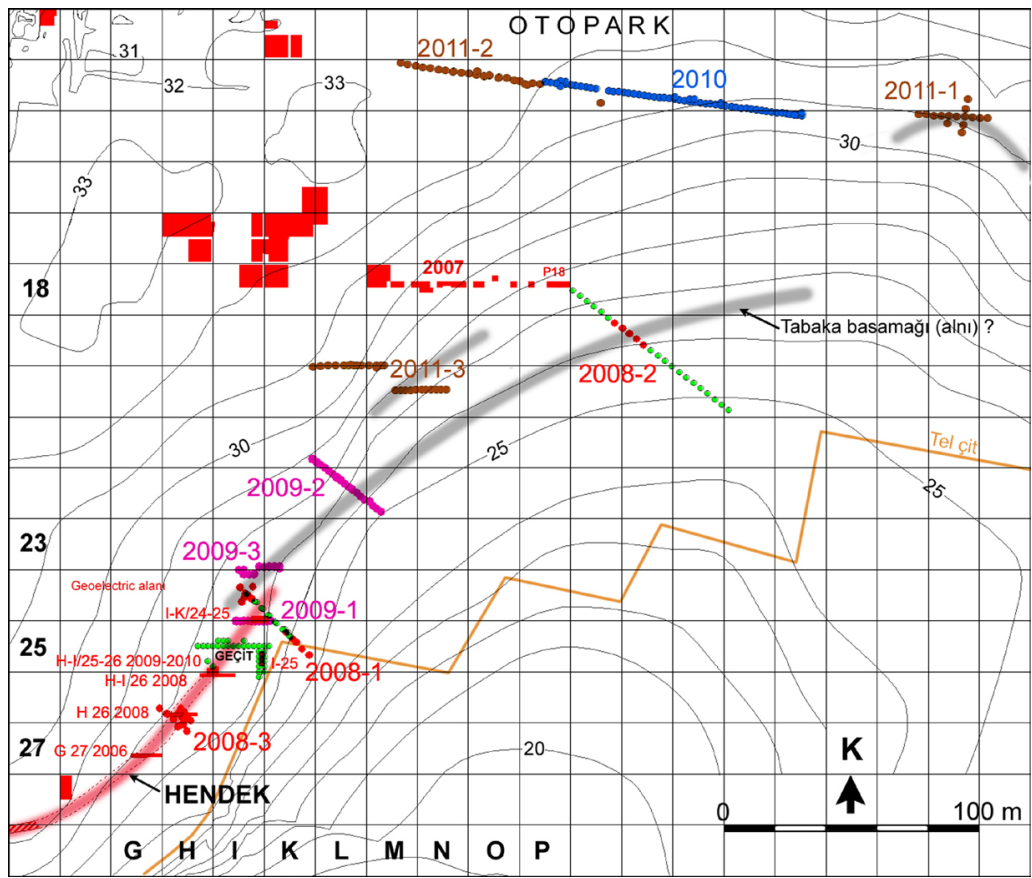

Fig. 6. Troya Aşağı Kent alanını güneyden çevreleyen savunma hendeğinin doğuya devamında yapılan delgi sondajların yerleri ve yılları. Sondajlar hendek uzanımı olarak öngörülen doğrultuya dik profil çizgileri üzerinde 2-3 m aralıklarla yapılmıştır. Böylece, belirlenen anakaya yüzey profilindeki çukurlukların hendek uzantısı olup olamayacağı, içlerindeki buluntulara (özellikle çanak-çömlek parçaları) göre arkeologlar tarafından değerlendirilmiştir. Küçük yeşil yuvarlaklar Unimog, diğer renklerdekiler yıllara göre Cobra delgilerini göstermektedir. (Altlık olarak kullanılan arkeolojik veriler Jabonka vd. 2011 den alınmıştır)

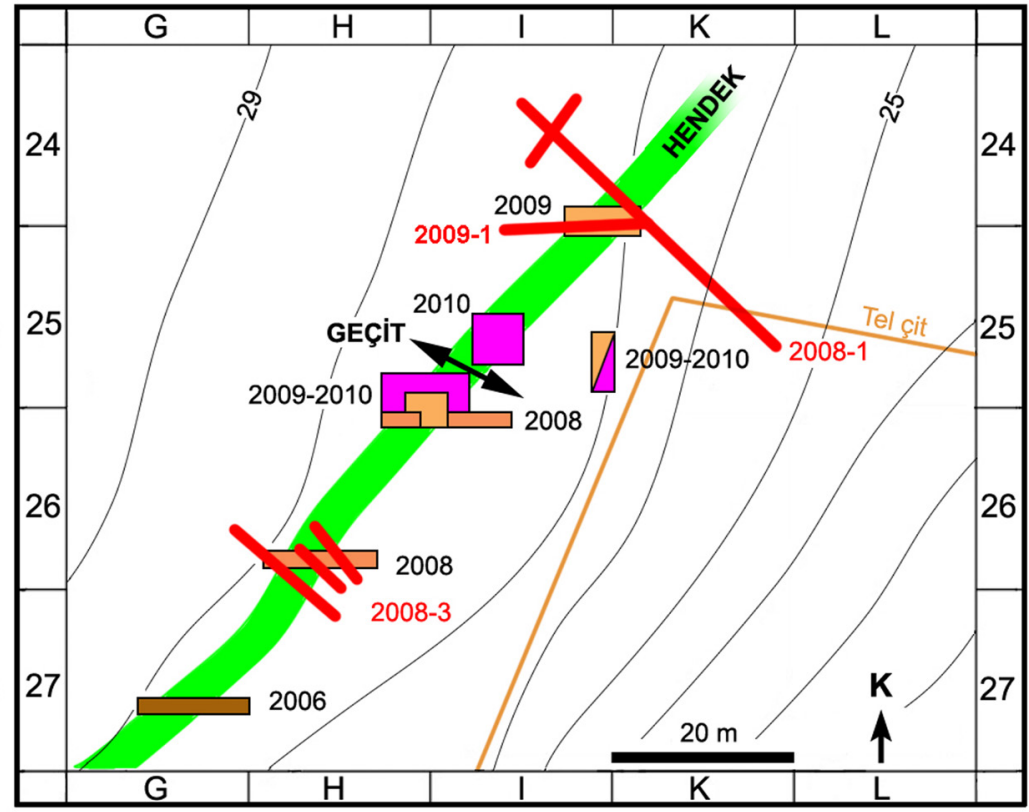

Fig. 7. Troya Aşağı Kent alanını güneyden çevreleyen savunma hendeğinin doğuya devamında yapılan çalışmalar. Üstteki planda renkli dörtgenler, sondaj verileri de dikkate alınarak yapılan arkeolojik kazı alanlarını (siyah rakamlar açıış yılları), kalın kırmızı çizgiler delgi sondajlarla oluşturulan kesit yerlerini (kırmızı rakamlar çalışma yılları) göstermektedir. (Altlık olarak Jablonka vd. 2011, ST:19, Fig. 5 den yararlanılmıştır). Altta, belirtilen grid karelerinde arkeolojik kazılarla açığa çıkarılan hendek bölümleri görülmektedir. Soldaki fotoğraf hendek üzerinde bırakılan geçit yerine aittir. Geçit kenarındaki kapı direğinin oyuğu ve kapının sürtünme izi dikkati çekmektedir. Sağda ise geçidin kuzeydoğuya uzanan bölümü görülmektedir. Buradan daha kuzeyde veya kuzeydoğuda hendeğin uzanımı izlenememiştir. Fotoğraflarda hendek içinde ve üzerindeki duvarlar arkeologlarca Roma Çağına tarihlendirilmiştir. (Fotoğraflar Jablonka vd. 2011, ST: 19 dan alınmıştır) 


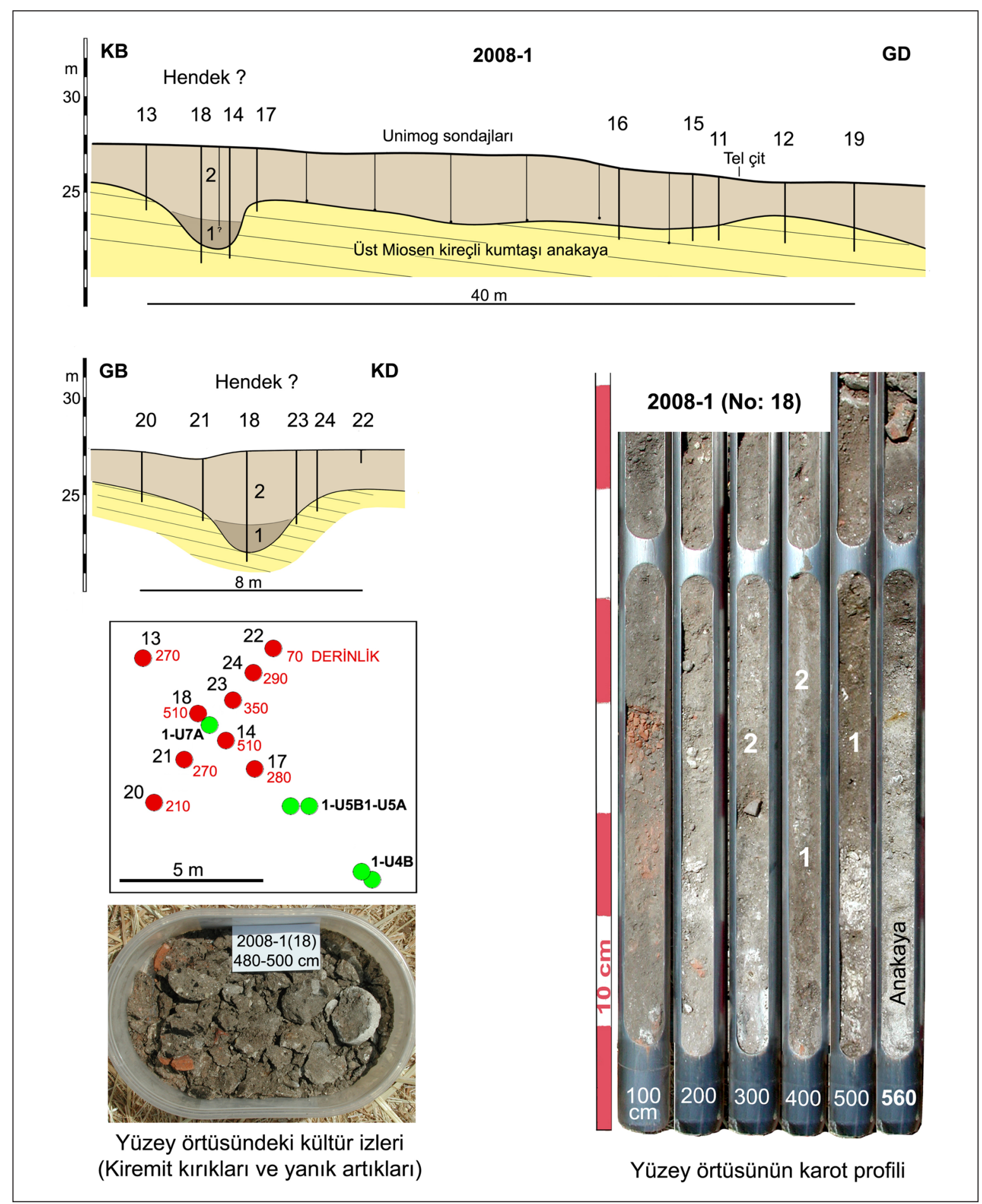

Fig. 8. Troya VIsavunmahendeğinin AşağıKent doğusundakiuzanımınıbelirlemekamacıylayapılan 2008-1 sondaj çalışmasınaaitkesitvedeğerlendirmeler(Bkz.Fig.6ve7).1)Yüzeyörtüsününanakayayıkaplayan, dahakoyurenkli,yanıkunsurlariçerenaltbirimi.2)Yüzeyörtüsünündahaaçıkrenkliüstbölümü.Buikibirimheryerdeayırtedilememiştir. 


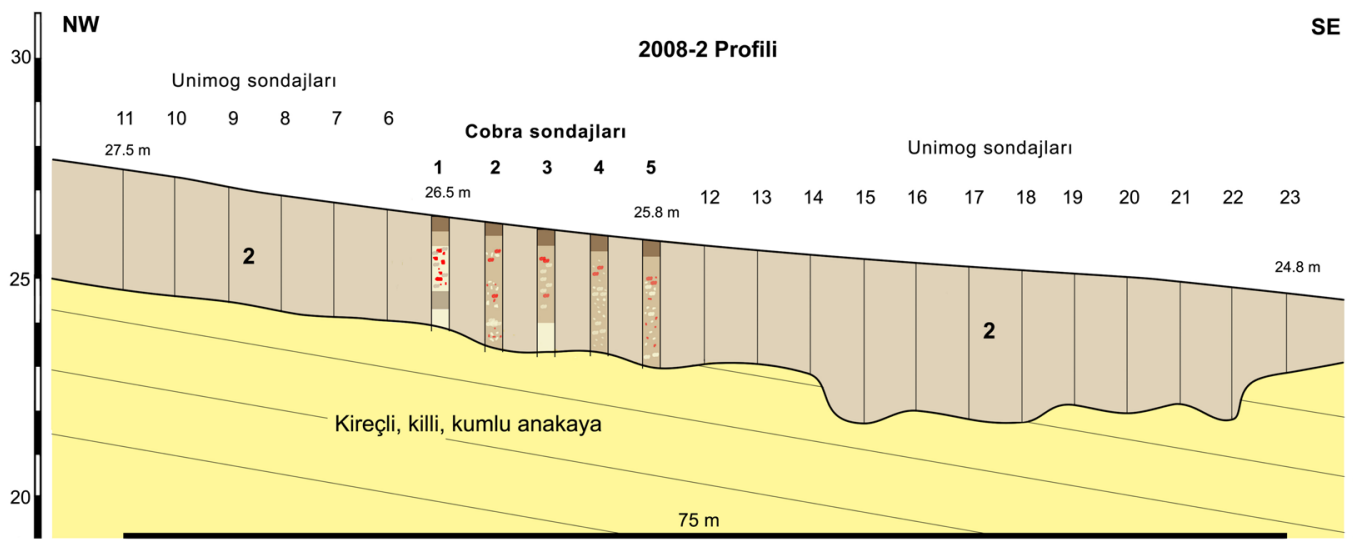

Fig. 9. 2008-2 profili (Bkz. Fig. 6). Unimog ile başlanıp, Cobra delgi ile tamamlanan kesitte, 2-3 m kalınlıktaki taşlı, tuğlalı enkazdan oluşan yüzey örtüsü (2) altında; güneydoğuya hafif eğimli, kireçli, killi, kumlu Üst Miosen tabakalarından oluşan anakayanın bulunduğu görülmektedir. Anakayanın hafif arızalı yüzeyinde hendek profilini ayırt etmek mümkün olmamıştır.
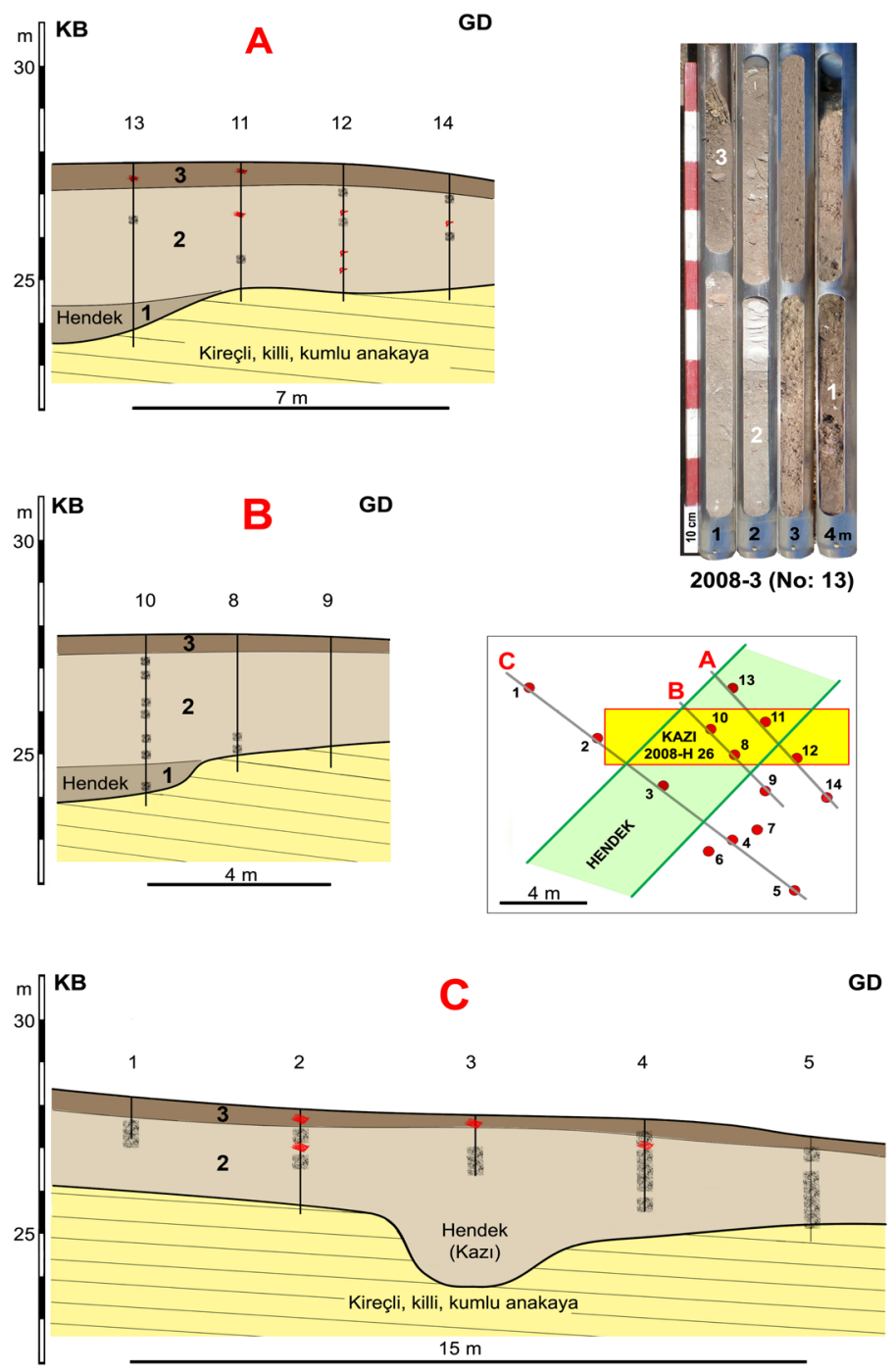

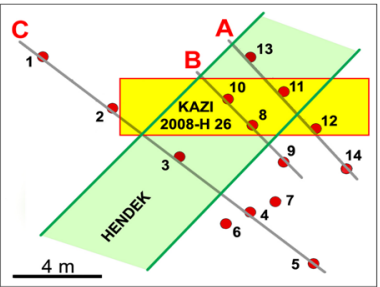

GD
Fig. 10.

Troya VI savunma hendeğinin Aşağı Kent doğusundaki uzanımını belirlemek amaciyla yapılan 2008-3 sondaj çalışmasına ait kesit ve değerlendirmeler (Bkz. Fig. 6, 7). Planda gösterilen 14 delgi sondajdan çoğunda taşlardan ilerlemek mümkün olmamakla birlikte, litolojik farklılıklardan yararlanılarak hendek yeri belirlenebilmiş ve yapılan kazıda bu doğrulanmıştır. Burada 13 ve 10 numaralı delgi verileri belirleyici olmuştur. 1) Koyu renkli, alt örtü birimi, 2) Açık renkli örtü birimi, 3) Yüzey toprağı. 


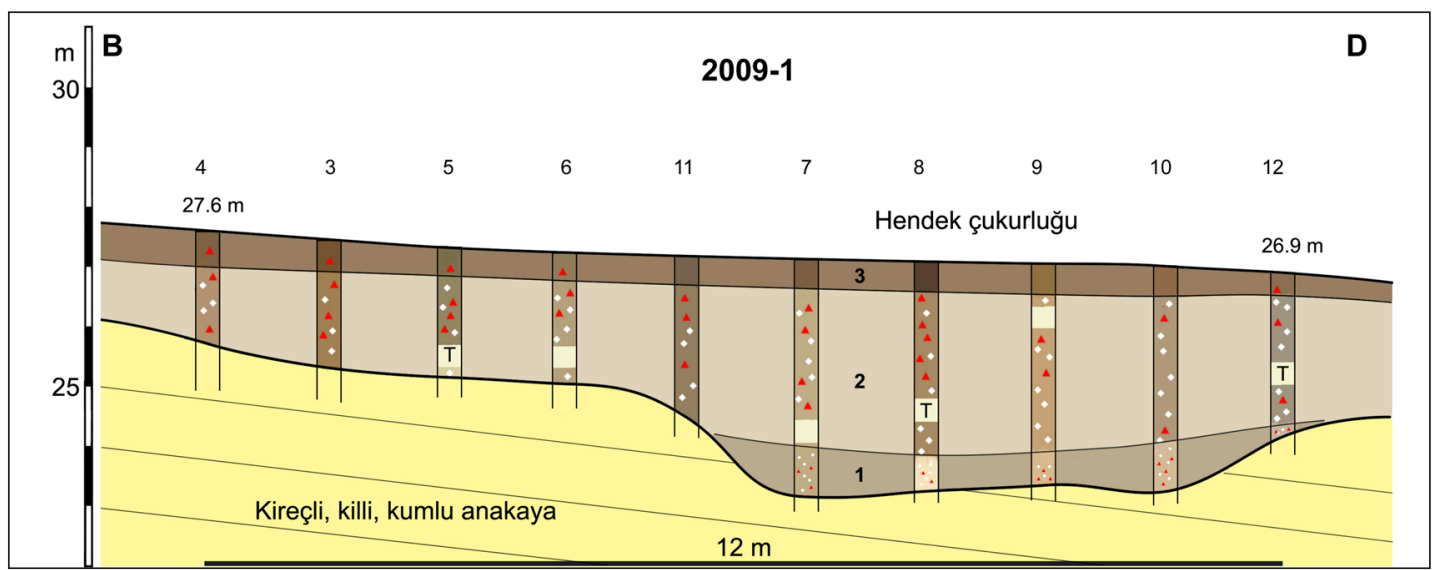

Fig. 11. 2009-1 profili. Batı-Doğu doğrultulu profil üzerindeki çukurluk, tabanını kaplayan dolgu içindeki arkeolojik materyalin (1: özellikle çanak çömlek kırıkları) arkeologlarca Geç Tunç Çağına tarihlenmesiyle, dönemin savunma hendeği olarak tanımlanmış ve yapılan kazıda bu değerlendirmenin doğru olduğu görülmüştür (Fig. 7: I-K 24-25). 2: Daha geç dönemlerin (Helenistik, Roma) taşlı, tuğlalı enkaz örtüsü, 3: Yüzey toprağı.

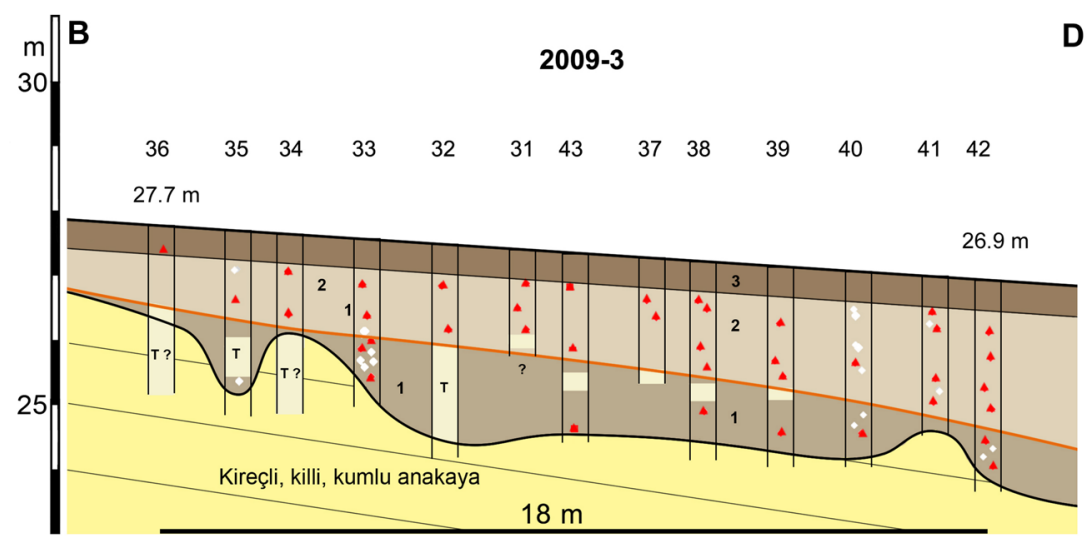

Fig. 12. 2009-3 profili (Bkz: Fig. 6). Burada da 2009-1 profiline benzer özellikler bulunmakla birlikte, anakaya yüzeyindeki arızalılık içinde hendek kanıtı olan bir arkeolojik bulguya (örneğin 1 içinde Geç Tunç Çağına ait bir unsura) rastlanmamıştır.

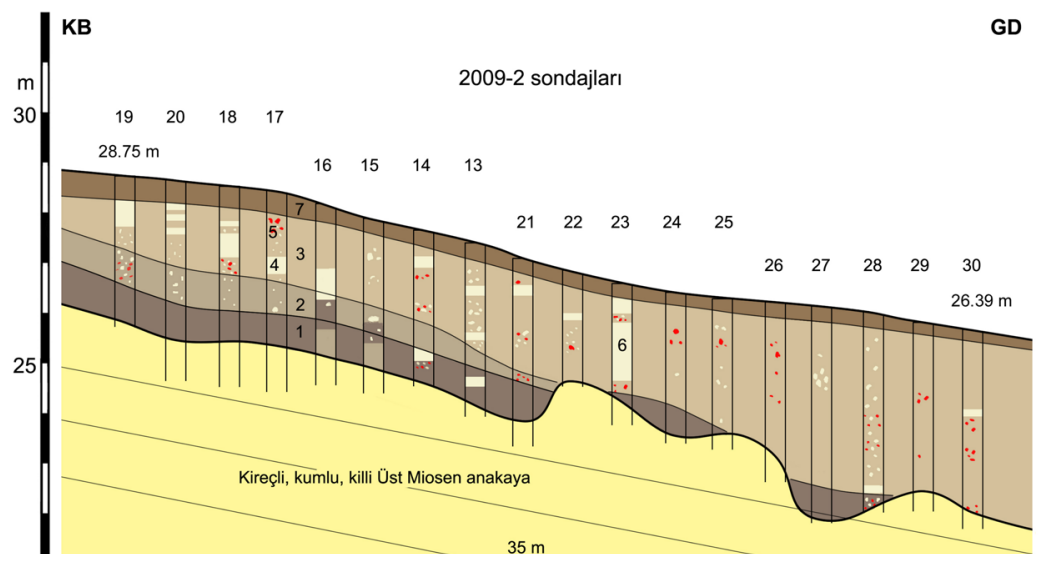

Fig. 13. 2009-2 profili (Bkz: Fig. 6). Burada da anakaya yüzey arızalılığı içinde hendek olarak nitelenebilecek bir çukurluk ayırt edilememiştir. 1 ve 2) Tabandaki koyu renkli, ince dokulu enkaz yayıntısı, 3: Geç dönem enkaz örtüsü, 4) Blok yapı taşları, 5) Genellikle iri tuğla kırıkları, 6) Muhtemelen duvar, 7) Topraklaşmış yüzey katmanı. 


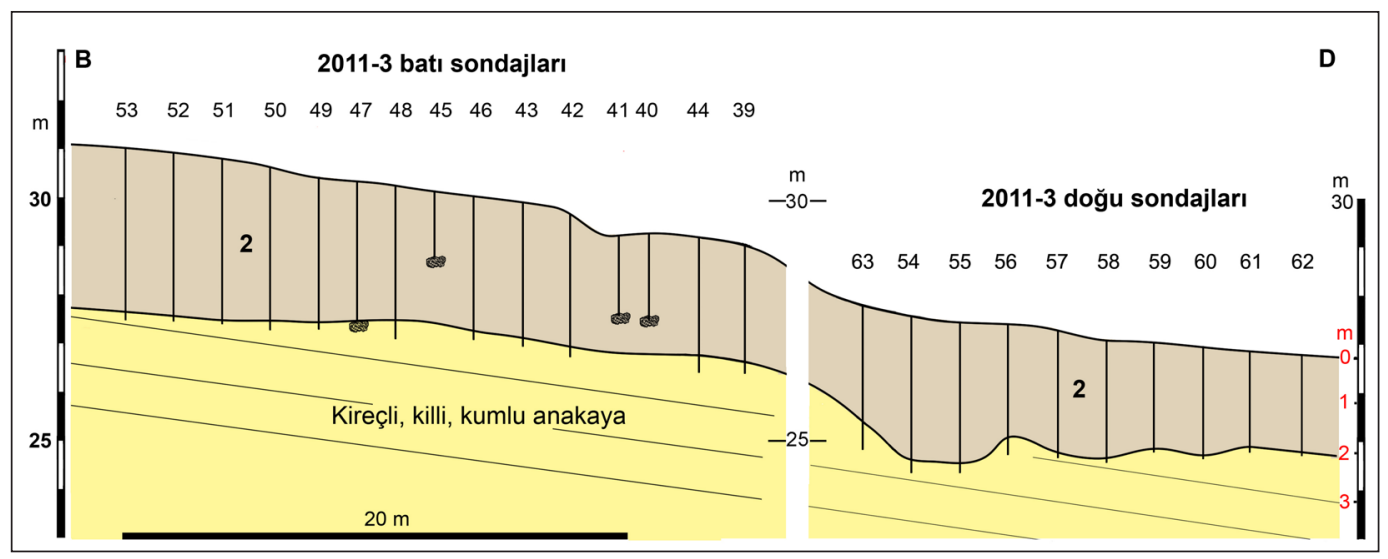

Fig. 14. 2011-3-3a profili (Bkz: Fig. 6). Hendeğin doğuda kuzeye yönelebileceği düşünülerek yapılan delgi sondajlarda, bu alandaki diğer yerlerdekine benzer şekilde az arızalı anakaya yüzeyinin taşlı, tuğlalı bir enkaz örtüsü (2) ile kaplı olduğu anlaşılmış, ancak Troya VI savunma hendeği olarak nitelenebilecek bir unsur bulunmamıştır.
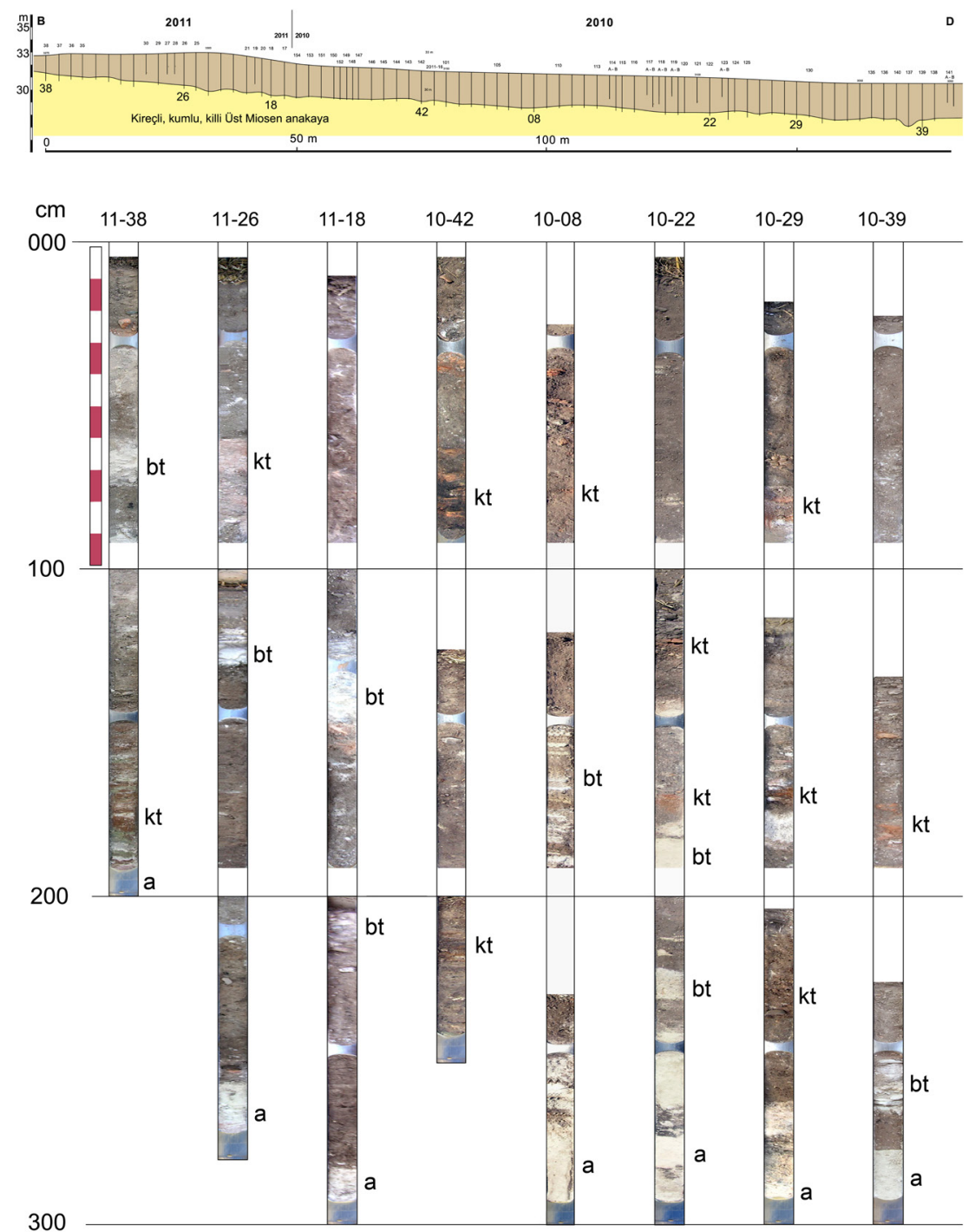

Fig. 15.

Otopark güney sınırında 2010 ve 2011 yıllarında yapılan toplam 85 çakma-delgi sondajla oluşturan kesit ve örnekleme karotlar (log'lar) (Bkz. Fig. 3, 6). Burada Üst Miosen, yataya yakın duruşlu kireçli, killi, kumlu tabakalardan oluşan anakaya yüzeyi oldukça düzdür (Kesitteki küçük arızalılık yükseklik ölçeğinin abartılı olmasıyla ilgilidir). Anakaya yüzeyinin hemen üzerinde kültür unsurları (çanak çömlek kırıkları, tuğla ve kiremit parçaları, yapı taşla$\mathrm{rl}$, seyrek olarak yanık kemik ve tahta-bitki kırıntıları) içeren, 2-2,5 m kadar kalınlıkta taşlı-topraklı bir örtü bulunmaktadır. Alttaki karot kesitlerinde, ölçeğin elverdiği boyutta olanlar işaretlenmiştir (a: Anakaya, bk: Blok yapı taşı, kt: Kiremit ve tuğla kırıkları). Bu alanda doğal aşınma ve birikme süreçlerinin etkisi zayıf olup, yüzey örtüsü enkaz yayıntısından oluşmaktadır. Doğru örnek alınamayan bölümler boş bırakılmıştır. 


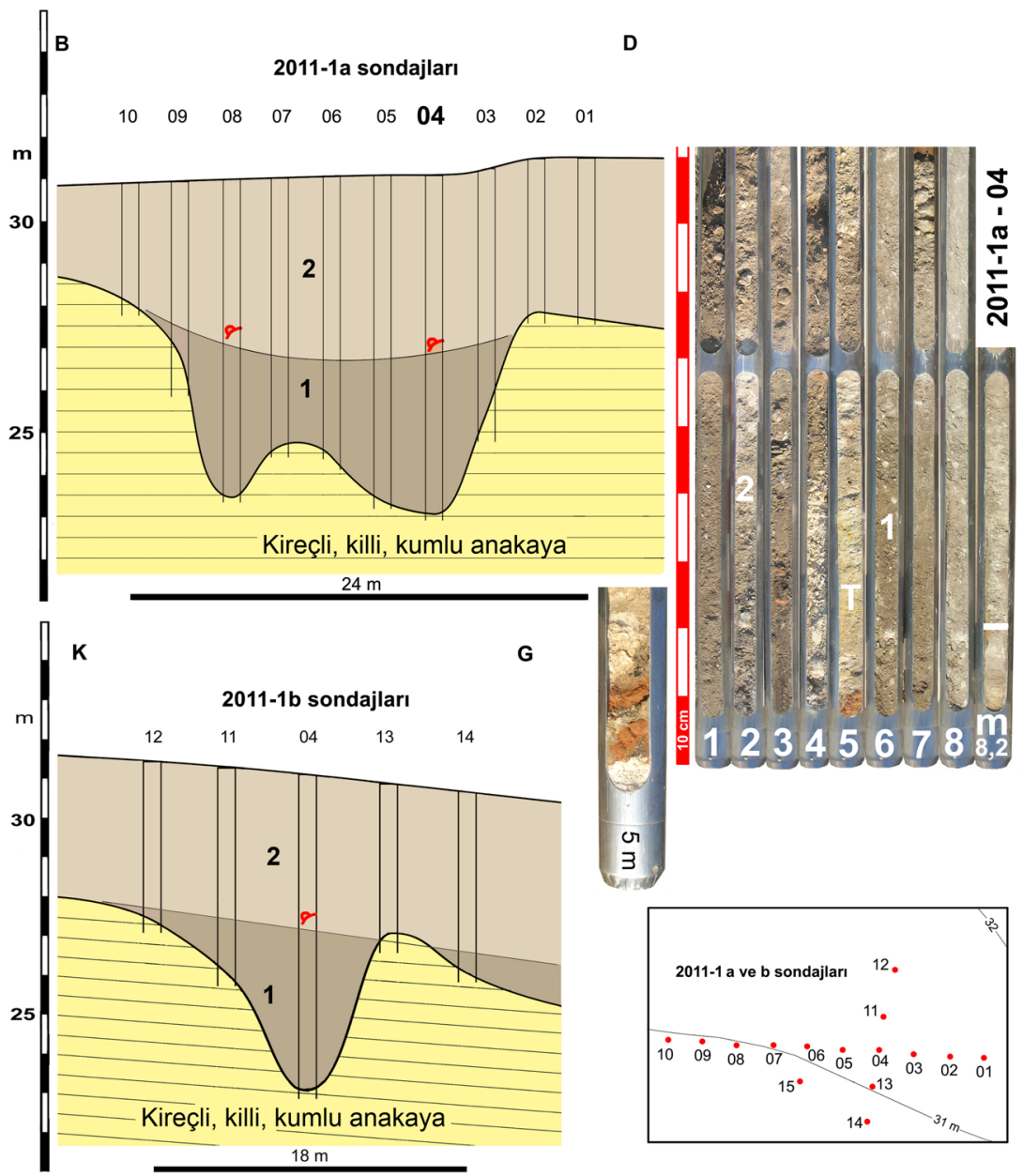

Fig. 16. 2011-1 a ve b profilleri (Bkz: Fig. 6). Otopark güneydoğusunda, daha önce Unimog ile belirlenen bir çukurluğun hendek uzantısı ile ilişkisi olup olmadığının araştırılması için yapılan delgi sondajlarda da çukurluk tabanında koyu renkli, küçük boyutlu enkaz kırıntıları içeren bir dolgu (1) bulunmakla birlikte, çukurluğun doğal bir anakaya yüzey arızası olduğu ve hendekle ilgisi bulunmadığı anlaşılmıştır. Çukurluğun üst bölümü (2), çevredeki diğer alanlar gibi taşlı, tuğlalı daha geç dönem enkaz örtüsü ile kaplı bulunmaktadır.Blok yapı taşı, kt: Kiremit ve tuğla kırıkları). Bu alanda doğal aşınma ve birikme süreçlerinin etkisi zayıf olup, yüzey örtüsü enkaz yayıntısından oluşmaktadır. Doğru örnek alınamayan bölümler boş bırakılmıştır.

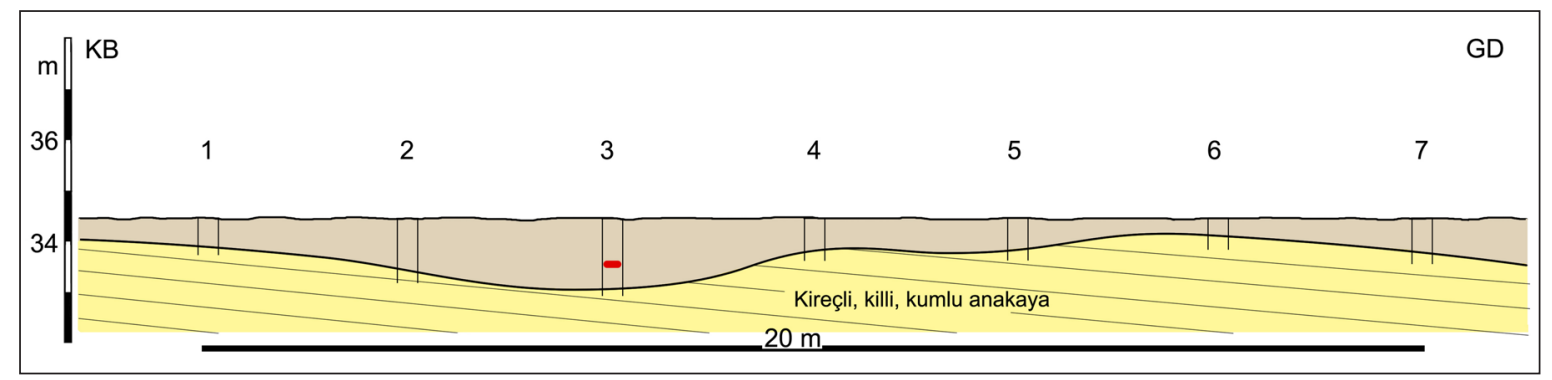

Fig. 17. 2008-4 profili (Bkz: Fig. 3). Eski kazı köyü (Bademli) doğusundaki alanda jeofizik anomalinin araştırılması için yapılan delgi sondajlarda konu ile ilgili bir bulguya rastlanmamış, anomali çizgisinin, 3. sondajın 80-110 cm derinliğindeki pişmiş topraktan bir su borusuna (künk) ait olduğu anlaşılmıştır. 

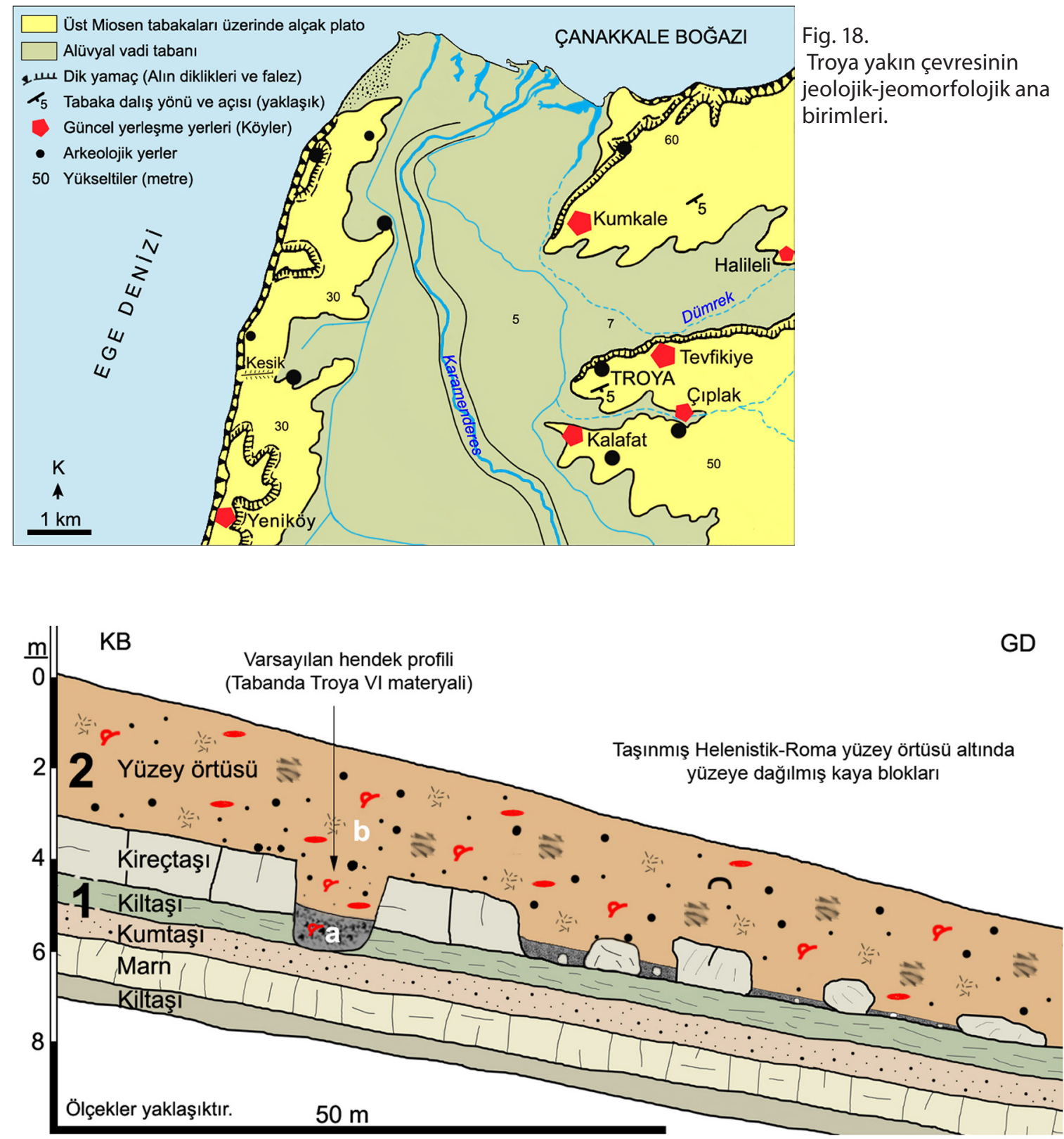

Fig. 19. Troya Aşağı Kent doğu kesiminde jeolojik yapı ve yüzey örtüsünün şematik kesiti. 1. Anakaya Üst Miosen (Neojen) sığ deniz tortul tabakalarından oluşmaktadır. Litolojileri çeşitli olan tabakalar hafifçe güneydoğuya eğimlidir. Çalışma alanında olduğu gibi, üstte çatlaklı ve kırılgan karbonatlı tabakaların bulunduğu yerlerde, tabaka kenarlarında (alınlar) kaya kopmaları ile yüzeyin arızalanması doğaldır. Böyle alanlardaki çukurlukların, kazı yapılmadan hendek çukurluğundan ayrılması zordur. 2. Yüzey örtüsü. Doğal bir birikme alanı olmayan yüzey (yapısal plato yüzeyi), genellikle çağlar boyunca yıkılan kerpiç binaların enkazı ile kaplıdır. Bu nedenle, toprak görünümü yanında, içinde çanak çömlek, kiremit kırıkları, yanmış ahşap parçaları, kemikler, kavkı kırıntıları gibi kültür işareti unsurlar bulunmaktadır. a) Erken dönemlerin (Tunç Çağları) enkaz yayıntılarını içeren birikintiler (Şematik-Varsayım). b) Geç dönemlerin (Helenistik-Roma) enkaz yayıntılarını içeren yüzey örtüsü. Kültür unsurları içeren örtünün doğrudan anakaya yüzeyini kaplaması, Troya erken dönemlerinde yüzeyin toprak örtüsü bulunmayan çıplak anakayadan ibaret olduğunu göstermektedir. Bu durum bütün Troya yerleşme alanı için geçerlidir. 